\title{
The Indian Ocean Tsunami: Economic Impact, Disaster Management and Lessons
}

\author{
Prema-chandra Athukorala \\ and \\ Budy P. Resosudarmo \\ Division of Economics \\ Research School of Pacific and Asian Studies \\ Australian National University \\ E-mail: prema-chandra.athukorala@anu.edu.au \\ budy.resosudarmo@anu.edu.au
}

Abstract: The purpose of this paper is to document and analyze the immediate economic impact of the Indian Ocean tsunami generated by the Sumatra-Andaman earthquake of 26 December 2004 and the disaster management process in the immediate aftermath of the disaster with a focus on the two worst affected countries - Indonesia (Aceh province) and Sri Lanka. The 26 December Tsunami is unique among large disasters in recorded human history, not only because of the sheer number of causalities and massive displacement of people, but also because of the unprecedented international donor response and the logistic challenges faced by international organizations and aid agencies in organizing and coordinating relief efforts. Our preliminary findings points to the importance of educating the public about simple precautions in the event of a disaster and enforcement of coastal environmental regulations as disaster prevention policies. The findings also makes a strong case for designing policies and programs, as an integral part of national development strategy, for mitigating the impact of natural disasters on the poor and highlights the need for combining international aid commitments with innovative approaches to redressing problems of limited aid absorptive capacity in disaster affected countries.

Key Words: tsunami, disaster management, Indonesia, Sri Lanka

JEL Classification: I32, O53 Q54

Forthcoming in Asian Economic Papers 


\section{The Indian Ocean Tsunami: Economic Impact, Disaster Management and Lessons*}

Sociologist, psychologists, historians, and policy planners have all devoted considerable attention to the nature, sources, and consequences of disaster and recovery, but the professional economic literature is distressingly sparse. ...Y Yet disasters are natural economic experiments; they parallel the tests to destruction from which engineers and physicist learn about the strength of material and machines. Much light would be thrown upon the normal everyday economy if we understood behaviour under conditions of great stress.

Jack Hirshleifer 1993

\section{Introduction}

With a death toll of about 350 thousand, the Indian Ocean tsunami caused by the deepsea earthquake near northern Sumatra on 26 December 2004 is by far the worst natural disaster of that kind in the recoded human history. ${ }^{1}$ Quite apart from the sheer number of deaths, the Indian Ocean tsunami has at least two unique features, which make it a valuable laboratory for the study of disaster management issues in the new millennium. First, it is the world's first truly global disaster, with lives shattered in a dozen of countries in two different continents. Second, the response to the disaster has also been global in a way rarely seen before, with tens of millions of ordinary citizens reaching into their pockets to send aid, in addition to donor governments and agencies. In some donor nations such as the UK, USA, Italy and Germany private donations surpassed the sizable government aid commitments and for the first time corporate donors figured prominently among private donors.

\footnotetext{
${ }^{*}$ Revised of a papers presented at the Asian Economic Panel Conference, Keio University, Tokyo, 6 - 7 March 2005. The authors are grateful to Jeffrey Sachs, Wing Thy Woo, Chalongphob Sussangkarn and other conference participants for helpful comments. The first author would like to thank the Institute of Policy Studies, Colombo and its Executive Director, Dr Saman Kelegama for invaluable institutional support for undertaking the Sri Lankan case study.

1 The death toll reported here Includes unaccounted (missing) people (142 thousand). The five previous deadliest tsunami (with the death toll in bracket) are: Indonesia: 27 August 1883 (36,000), Portugal: 1 November 1755 (30,000), Japan: 15 June 1896 (27,000); Japan: 21 May 1792 (14,000), and Japan: 27 March 1933 (3,000) (Abbott, 2004, Table 3.7).
} 
The first feature, the vast geographic spread of the disaster, produced a huge logistic challenge for international organizations and aid agencies. It also rekindled international interest is in setting up a global disaster monitoring system and other cooperative initiatives to increasing public awareness of calamities of this nature at the global and regional level. The second feature, massive tsunami aid flows, has drawn attention to a number of new issues of international aid operations, including avoiding duplication of tasks, setting up procedures for translating aid pledges into actual aid flows and finding ways and means of avoiding untoward effects of massive aid inflows in an unplanned fashion to the affected countries. The unprecedented preference shown by individual donors to informal private channels has thrown into sharper relief the veining public confidence in aid organizations and receiving-country governments. In addition, the devastation caused by the tsunami has begun to reveal a close connection between the magnitude of the damage caused by the killer waves and the violation of environmental regulations in the affected countries. Although the height of the waves and their global spread were purely the work of nature, there is clear evidence that the sheer number of losses of human lives was partly a result of modern progress, ruthless destruction of natural defenses such as coral forests and mangrove swamps, and building oceanfront hotels and villas in violation of coastal conservation legislation.

The purpose this paper is to document the nature and extent of the disaster, and to undertake a preliminary analysis of the economic impact and disaster management process in the immediate aftermaths of the disaster, in order to set the stage for deeper analysis of these and related issues. The paper is arranged in three main sections. It begins with a broad-brush picture of the tsunami disaster - the nature and extent of the calamity and the international donor response - from a comparative perspective. The next two sections contain case studies of the two worst affected countries - Indonesia (Aceh province) and Sri Lanka. The case studies follow a common format, focusing in turn on the history of natural dissenters and the preparedness (or rather lack of it) for facing them, the economic impact of the tsunami and the crisis management experience to date. The final section summarizes the key findings and policy lessons. 


\section{The Indian Ocean Tsunami: An Overview}

On 26 December at 0059 GMT (just before 8 am local time) an earthquake measuring 9.0 on the Richter scale occurred about $30 \mathrm{~km}$ off the west coast of Sumatra, the extreme western end of the 'Ring of Fire' (a zone of frequent volcanic eruption partly encircling the Pacific Basin that accounts for over 80 percent of the world's largest earthquakes). This was the fifth largest earthquake for a century and the largest after the one erupted in Prince William Sound in Alaska in 1964 (9.2 on the Richter scale). It ruptured about $1300 \mathrm{~km}$ of the fault boundary between the Indo-Australian Plate under the southeastern Eurasian plate, slipping the former under the latter and lifting the seabed by as much as by 5 meters (16 feet). The initial energy released by the eruption was estimated at about 25 Hiroshima bombs (Lay et al. 2005).

The tsunami split about 8 minutes after the rupture, sending energy pulses east towards the Sumatra coast and west across the open seas in the Bay of Bengal at a speed up to 800 $\mathrm{km}$ an hour (the speed of a modern jet plane at full throttle). The eastward-moving wave traveled through first, pulling water away from shores. So the westward, long-distance tsunami processed crest first. The height of the leading tsunami wave increased to as much as 24.4 meters as it approached in 28 minutes the shallow waters of the Aceh province of Sumatra (National Geographic, 2005). Meanwhile the long-distance tsunami widened its arc as it continued west, affecting coastal areas of Thailand, Myanmar, India (Tamil Nadu, and Andaman and Nicobar Islands), Malaysia, Sri Lanka, Maldives, Somalia, Kenya and Tanzania (See Map 1).

The Aceh province, the land mass closest to the east of the epicenter of the earthquake, had to bear the full brunt. Sri Lanka was the next worst affected because there was no landmass between it and the epicenter to cushion the coastlines in the north, east and the south. The fault line of the earthquake was in a north-south orientation. The great strength of the long-distance tsunami was therefore in east-west direction. This explains why Bangladesh, which lies on the northern end of the Bay of Bengal, had very few casualties despite being a low-lying country regularly devastated by cyclones and why Somalia was hit harder than Bangladesh despite being far away from the epicenter. The 
physical oceanography of the Indian Ocean during the month of December also seems to have played a role in determining the path and the severity of the tsunami waves. In the month of December under the North East Monsoon the equatorial Indian Ocean jet propagates along the equator from Sumatra (near the epicenter of the earthquake) slightly to the South of Sri Lanka and to Somalia. This was perhaps an additional reason why the impact of the waves was so severe in Sri Lanka, the Indian state of Kerala was badly hit despite the cover provided by the landmass of Sri Lanka, and the impact on Somalia (and also Kenya and Tanzania) was disproportionate to the long distance from the epicenter.

\section{Map 1 about here}

The Pacific Tsunami Monitoring Centre (PTMC) in Honolulu, Hawaii ${ }^{2}$ detected the earthquake 18 minutes after the eruption and issued an e-mail communiqué to the Pacificnation member countries saying that there was no threat to them. A second communiqué indicated the possibility of a tsunami affecting countries in the Indian Ocean Sixty-five minutes later. This information was, however, not communicated to the countries in the Indian Ocean region, as the PTMC officials did not have required contracts in their address book. There was no warning system in place in the Indian Ocean. Even if the information were made available, it would not have made a big difference because these countries had no effective civil defense mechanism for getting the information to the people. Moreover, unlike in the Pacific Ocean, tsunami has been a very rare occurrence in the Indian Ocean and historically tsunami-related calamities had been of minor importance compared to other natural disasters (Abbott, 2004, Ch. 3; Albala-Bertrand 1993, Ch. 2).

The 26 December tsunami was first and foremost a human tragedy. Total official death toll had passed the 220 marked by mid February 2005, with over 50 thousand people still

\footnotetext{
2 The International Tsunami Warning System was first established as part of the US Government's national Oceanic and Atmospheric Administration following the disaster caused by the tsunami of April 1, 1946 in the Hawaiian Islands. The coverage of the system was extended to military bases throughout the Pacific and to islands in the Trust Territories. Beginning in October 1953, warning information was extended to California, Oregon and the State of Washington. A large number of countries joined the system after the May 1960 Chilean tsunami and the tsunami generated by the great Alaskan earthquake of 1964.
} 
missing (presumably also dead) (Table 1). The Secretary General of the UN, Kofi Annan described the catastrophe as 'the largest natural disaster the organization has had to respond on behalf of the world community in the 60 years of our existence'. The macroeconomic impact on Indonesia, India and Thailand is unlikely to be severe compared to the shocking human toll. Despite the misery, the impact on regional GDP growth rate in 2005 is likely to be modest. However, by virtue of its economic sizes, the immediate and medium-term impact on economic growth is proportionately much greater in Sri Lanka and Maldives than in Thailand, Indonesia and India. The region’s financial markets remained ‘strangely serene’ (EIU 2005, p. 1). Currencies have not been collapsed, and in Sri Lanka massive aid commitments triggered a significant appreciation of the nominal exchange rate (see below). The main reason for the limited economic impact was that the tsunami missed the industrial and commercial centres of all affected countries other than Maldives. The impact on the global financial market was rather muted because many of the damaged facilities were uninsured, minimizing the exposure of Western and Asian financial services companies to the tsunami destruction. ${ }^{3}$ Massive aid pledges also played a crucial cushioning role in maintaining business confidence in the affected countries, in addition, of course, to facilitating relief operations in the aftermaths of the devastation.

\section{Table 1 about here}

The donor response to the tsunami crisis has been unprecedented. According to records maintained by the Office for the Coordination of Humanitarian Aid (OCHA) of the United Nations, 78 countries, thirty organizations and individual donors had pledged US\$ 6.3 billion by 21 February 2005 (Table 2). In addition, there were unprecedented direct private contributions, which according to some estimates amounted to more than 1.6 billion. $^{4}$ In some donor countries such as the UK, USA and Italy private contributions exceeded the sizable government contributions by a wider margin. When the total

\footnotetext{
${ }^{3}$ Munich Re estimated that its total exposure will be less than Eoru 100m (US\$ 13mn), while Swiss Re, the world's second largest insurer, said its exposure should be under US\$88mn (EIU 2005).

${ }^{4}$ This estimate is based on Chandler 2005; Economist 2005c, and information obtained from www.lanklibrary.com (based on Reuters reports).
} 
official aid pledges and private donations (individual and corporate) are taken together (about US\$ 8 billion) and relates to an estimated number of around 5 million people directly affected by the disaster (Table 1), per head aid contribution turns out to be over US\$ 1000. The norm in previous international fund raising attempts in face of natural disasters has been a mere US\$40 per head (Economist 2005d).

\section{Table 2 about here}

In addition to direct aid pledges, the Paris Club of creditor nations declared at its January 12 meeting in Paris a moratorium on the foreign debt of the tsunami hit countries. ${ }^{5}$ Some key players of the international aid community, including the World Bank president James Wolfensohn, suggested that debt write-offs would be preferable to debt deferral. However, this proposal was not accepted because it raised the so-called 'moral hazard' problem; countries absolved of debt might borrow excessively or recklessly in future in the expectation that they would eventually be bailed-out. The IMF and World Bank officially endorsed the moratorium and the major international credit rating agencies declared that they would not take into account deferral of debt service payments as a negative factor in their risk assessment and credit rating. Subsequently, the IMF and the World Bank also announced considerable debt relief for the affected countries, in particular for the Maldives, Sri Lanka and Indonesia. In February 2005, the Asian Development Bank set up a US\$600 million Asian Tsunami Fund to deliver grants for emergency technical assistance and reconstruction projects.

\footnotetext{
${ }^{5}$ It is important to note that countries that choose to accept a debt moratorium would face larger repayments- a debt 'hump' - in the future years. A suspension of debt payments could carry other risks as well. Any suspension of debt payments might cause lenders to question the creditworthiness of borrowers (although the major credit rating agencies have declared that they would not downgrade tsunami-affected countries that accepted debt deferral). Countries that accepted debt deferral might also raise concerns among investors, who may worry if governments opt for a bail-out rather than face up to difficult economic decisions.
} 


\section{Indonesia}

\section{(a) A Historical Perspective of Natural Disasters}

Located in the "Ring of Fire", Indonesia has the largest number of active volcanoes in the world. Approximately 10 percent of the world's recorded seismic activity had occurs in the Indonesian archipelago (Tomascik et al. 1997). ${ }^{6}$ There are hundreds of volcanoes in the country, of which approximately 76 percent have been historically active. The majority of these are located in the arc of Sumatra, Java and the Lesser Sunda Islands. There have been around 1,171 recorded volcanic eruptions in Indonesia, a record which only slightly lower than that of Japan $(1,274)$. These two countries jointly account for $1 / 3$ of the known eruptions in the world, but Indonesia has suffered the highest numbers of fatalities, damage to arable land, mudflows, tsunamis, domes, and pyroclastic flows. Four fifths of Indonesia's dated volcanic eruptions have occurred in this century (USGS, 2003). Two of these eruptions are among the largest eruption ever in the world.

The contour and climate of the Indonesian archipelago also has the potential to cause other deadly natural disasters such as cyclone, drought and flood. According to records maintained by the WHO Collaborating Centre for Research on the Epidemiology of Disasters (CRED) at the Universite Catholique de Louvain, during the period from 1907 to 2004, there were approximately 312 events of deadly natural disaster in Indonesia, averaging to around 3 disaster per year (Table 3). On average, approximately 976 people died and approximately 51 thousand people affected per event. The Indonesian Emergency Relief Coordination Agency (Bakornas PBP) recorded that during 19972004 there were 796 cases of natural disasters (excluding the 26 December disaster), on average 99 cases per year or more than one each week (Table 4). These events killed approximately 37 thousand people, created 460 thousand refugees, and destroyed 68 thousand houses. The average (per-event) death toll of tsunami amounted to 960, compared to 140 relating to earthquakes and 37 relating to cyclones.

\footnotetext{
${ }^{6}$ This number is certainly big but much smaller compared to China. Forty percent of world earthquakes happened in China.
} 


\section{Table 3 about here}

\section{Table 4 about here}

Figure 1 about here

Figure 1 depicts the number of occurrences and magnitudes of earthquake (with magnitude equal and greater than 5 on the Richter scale) in Indonesia since 1907. Interestingly, both the frequency and the magnitude of earthquakes has been increasing throughout this period. The most severe natural disasters occurred in the country are as follows.

- Eruption of the Tambora volcano in the Sumbawa Island, West Nusa Tenggara (1815). This was the greatest volcanic eruption in recorded history (VEI=7). ${ }^{7}$ During this eruption, Tambora's cone with an estimated volume of $30 \mathrm{~km}^{3}$ was blown away and the total material erupted was approximately $100-300 \mathrm{~km}^{3}$. Ash of this eruption was found up to $600 \mathrm{~km}$ in the Indian Ocean toward the south but not toward the north. Ash layers with a thickness of $60 \mathrm{~cm}$ were found at a distance of $70 \mathrm{~km}$. This eruption killed approximately 92 thousand people. The tremendous amounts of ash thrown into the atmosphere resulted in an abnormally cold summer in the Northern Hemisphere (Tomascik et al. 1997).

- Eruption of the Krakatoa volcanic island located in Sunda strait between Java and Sumatra islands (1883). This eruption was the fourth greatest volcano eruption in recorded history. It emitted approximately $18 \mathrm{~km} 2$ of ash. The coast of Java and Sumatra were hit by at least 19 tsunamis, with the largest estimated at 30-40 m high. The clouds of dust, gases, and debris rose approximately $27 \mathrm{~km}$ into the atmosphere, coloring sunsets for 2 years. The total death toll was approximately 36 thousand (Tomascik et al. 1997, Winchester 2003).

\footnotetext{
${ }^{7}$ The volcanic explocivity index. Eruptions with VEI equal and greater than 4 are considered large eruptions. An eruption with VEI equals 4 happens once a year (around the world). An eruption with VEI equals 5 or 6 happens once every around 100 years. An eruption with VEI equals 7 happens once every around 1000 years.
} 
- Eruption of Kelut volcano located in the East Java, not so far from relatively populated towns of Kediri and Blitar. This volcano has erupted several times and two eruptions have caused fatalities. First eruption (VEI $=5$ ) was in 1586. It produced one of the worst lahar in historical record of volcanic eruptions and took the lives of about 10 thousand people. Second (VEI=4) was in 1919. In this case, lahars traveled as far as $38 \mathrm{~km}$ in less than an hour and devastated an area of more than 15 thousand hectares of arable land, destroying hundred villages and killing approximately 5 thousand people (Bergen et al. 2000).

- Earthquake occurred in Bali on the $21^{\text {st }}$ of January 1917 (NGDC 2004). This earthquake (6.5 on the Richter scale) and the resultant tsunami together destroyed more than thousand houses in the island. Around 15 thousand people died during this event. The death toll could have been much higher if it were not for the particular timing of the earthquake; it occurred in the morning when most people were already up and working in the rice fields. This is among the 25 deadliest earthquakes in the world so far.

- $\quad$ Earthquake and tsunami occurred on the Island of Flores (12 ${ }^{\text {th }}$ of December 1992). This earthquake (measured at 7.5 on the Richter scale) generated tsunami waves as high as 25 meters, which penetrated 300 meters inland, killing approximately 2,500 people, leaving around 90,000 were left homeless. Between 50 to 80 percent of houses and structures on the island were damaged or destroyed. There were also reported damages in surrounding islands such as Sumba and Alor (NGDC 2004).

- The two most severe droughts took place in 1966 and in 1997. The drought in 1966 killed approximately 8 thousand people and put approximately 204 thousand people in starvation, mostly in the island of Lombok (CRED 2005). An extreme El Nino in the Pacific caused the drought in 1997. Ocean surface temperatures were much warmer than normal in the east and cooler than usual near Indonesia, shifting rain away from Indonesia (Wheeler 2002). The drought killed approximately 5 hundred 
people and starved around 90 thousand people, mostly in Papua. The situation got worst since this drought induced forest fires destroying around 9.7 million ha forest resources and wild life habitat across the country, mostly in Kalimantan and Sumatra. The smoke haze affected millions of people in the region, including in Singapore, Malaysia and Thailand. Conservative estimates of the economic loss that occurred for Indonesia was over US\$ 4 billion (Applegate et al. 2002, Wheeler 2002, Glover and Jessup 1999)

In sum, Indonesia has been the victim of some of the worst natural disasters in the world. Moreover, there are clear indications that the frequency of natural disasters in Indonesia has been increasing over time.

\section{(b) The 26 December Earthquake and Tsunami}

The earthquake and tsunami on the 26th of December 2004 is the worst natural disaster in Indonesian history. Most people in Aceh and North Sumatra, and several regions in Indonesia, could feel the shake caused by the massive eruption that occurred at about 8 am that day. About 15 minutes later, tsunami hit the northern part of Aceh, the western part Aceh and North Sumatra as well as islands in those regions such as Nias and Simeulue islands. Waves as high as $10 \mathrm{~m}$ high and a speed of around $800 \mathrm{~km}$ per hour hit the city of Banda Aceh, which is located in the northern part of Aceh. In some places, waves went inland approximately $7.5 \mathrm{~km}$ from the coastline. Waves as high as $12 \mathrm{~m}$ hit cities of Meulaboh, Calang and Lamno - cities located in the western part of Aceh -and they submerged areas up to about $10 \mathrm{~km}$ from the coastline (Soehaimi et al. 2005).

By mid March 2005, the official Tsunami death toll in Indonesia was close to 167 thousand, with 128 thousand missing (most likely dead), and 648 thousand displaced (Table 1). According to figures released by the Department of Social Affairs on the $17^{\text {th }}$ of February 2005, around 920 people were in hospitals, and around 480 thousand people in refugee camps (Table 5). In term of number of people killed and missing, the city of Banda Aceh suffered the most; followed by the districts of Aceh Jaya and Aceh Barat. In term of percentage of population affected, Aceh Barat district suffered the most, followed 
by the city of Banda Aceh, Aceh Jaya and Aceh Besar in that order. The impact of the earthquake and tsunami is concentrated in these four districts.

\section{Table 5 about here}

Based on field visits and interviews in Aceh during and several weeks after the disaster, Aspinall finds that children, women and older people accounted for more than two thirds of the tsunami victims, dramatically changing the demographic structures in many villages and cities heavily hit by the tsunami. ${ }^{8}$ Unlike in Sri Lanka (see below), the death toll was much higher than the number of people hospitalized or became homeless.

An interesting case worth noting is the rather low death toll in Simeulue island, which is situated only about $100 \mathrm{~km}$ away from the epicenter. Simeulue Island was severely hit by the tsunami; approximately 5,500 houses were destroyed and hundreds of people suffered injury. However, only seven deaths were recorded (Kompas, 1 April 2005). There are two possible reasons for the surprisingly low death toll. First, the coastal ecosystem, namely the coral reef, sea grass and mangrove forests in the northern part of the island softened the force of the giant waves. Second, local culture in the island (adat) has an important precautionary procedure transferred from generations to generations for facing a tsunami. The procedure is as follows. Once one recognizes some indications of an impending tsunami, he/she would runs to the closest hill shouting 'smong....smong.....smong' (tsunami in local language). Others who hear the warning would run to the closest hill while contributing to the 'smong....smong.....smong' chorus. This simple procedure proved to be very effective in the recent tsunami (Wetlands International-Indonesia Program 2005). Unlike in Simeulue, simple traditional mitigation procedures imbedded in local culture have never existed or had simply been forgotten by the people in other areas in Aceh and North Sumatra.

Evidence of the importance of the coastal ecosystem in mitigating the impact of tsunami comes from the other affected areas in Indonesia as well. For instance, the impact of the

\footnotetext{
${ }^{8}$ Based on a discussion with Edward Aspinall, University of Sydney.
} 
tsunami was less severe in areas along the west and east coast of Aceh, where the coastal ecosystem remained in relatively good shape. The damage was much severe in coastal cities, where the coastal ecosystem has been disturbed by housing, tourism and destructive fishing, were affected more than other areas (Wetlands InternationalIndonesia Program 2005).

There are several agencies in Indonesia that have the responsible to monitor seismic activities and other natural disasters in the country, such as the Meteorology and Geophysics Agency (Badan Meteorologi dan Geofisika), Volcano and Geological Disaster Mitigation Directorate (Direktorat Vulkanologi dan Mitigasi Bencana Geologi) at the Ministry of Energy and Mineral Resources, and Center of Geological Research and Development (Pusat Penelitian dan Pengembangan Geologi). Since the Flores tsunami in 1992, these agencies, with the help of international institutions, have been conducting research on tsunami in Indonesia. Banyuwangi tsunami in 1994 and Biak tsunami in 1996 further encouraged such research. A few years ago, these agencies jointly produced a map indicating where tsunami events are most likely to occur. This initial work did not lead to the development of a systematic and comprehensive tsunami monitoring system because of unavailability of funding. However, even if such system existed, it may not have made a much of a difference in the recent tsunami; the epicenter of the earthquake was too close to Aceh and massive reached the land in fifteen minutes (Deutsche PresseAgentur 4 January 2005).

\section{(c) The Economic Impact}

The World Bank, using a standard assessment technique developed by the United Nations Economic Commission for Latin America and the Caribbean (ECLAC 2003), has estimated the total damages and losses caused by the earthquake and tsunami was approximately US\$ 4.45 billion or almost 100 percent of Aceh’s GDP in 2003 (Table 6). Of the total, 60 percent constitutes damages, while 40 percent constitutes losses in the term of income flows lost to the economy. Around 78 percent of the total damages and losses were born by the private sector and the rest by the public sector (World Bank, 
2005). The Institute for Economic and Social Research (LPEM) at the Faculty of Economics-University of Indonesia estimated the total damage in Aceh at US\$ 4.6 billion (LPEM 2005). According to LPEM estimates, around a third of the road network, schools and hospitals were destroyed by the tsunami (see Table 7). According to estimates by the Asian Development Bank (ADB) the giant waves flattened some 115,000 houses and severely damaged another 150,000 (ADB 2005, p. 11)

\section{Table 6 about here}

\section{Table 7 about here}

Aceh’s GDP in 2003 was approximately US\$ 4.5 billion, approximately 2.3 percent of total GDP of the national economy. Oil and gas industry and agriculture were two sectors that dominated Aceh's economy, contributing for 43 percent and 32.2 percent of the regional GDP, respectively. In agriculture, livestock (10 percent) and food crops (10 percent) contribute the highest share. The oil and gas industry escaped the tsunami virtually unharmed. The mostly affected sector is the agriculture, particularly fishery, both in terms of the number of casualties and capital destroyed (Soesastro and Ace 2005). According to the World Bank, Aceh's GDP could contract by 7 percent to 28 percent compared to the 2004 level (World Bank 2005). LPEM has come up with a slightly lower estimate of GDP contraction, 22.3 percent (LPEM 2005). The tsunami destruction in the province of North Sumatra was by and large concentrated in the district of Nias, the poorest district in the province whose contribution to the overall regional economy is rather small (Table 5).

According to information gathered by the Ministry of Marine Affairs and Fisheries, by mid January approximately 55 thousand fishermen and aquaculture workers were among the death (approximately a half of total fishermen in Aceh), while around 14 thousand fishermen and aquaculture worker were still missing. FAO (2005) reported that 40 to 60 percent of coastal aquaculture ponds along the coast of Aceh and between 36 thousand and 48 thousand ha of brackish water aquaculture ponds (that mainly produced shrimp and milkfish) were seriously damaged. It is estimated that about $65-70$ percent of the 
small scale fishing fleet and associated gear was destroyed in Aceh, representing approximately 9,500 units, of which 40 percent canoes, 25 percent with outboard motor, and 35 percent with diesel inboard motor.

In Aceh about 30 thousand hectares of rice fields, amounting to about 10 percent of the total area under rice cultivation in the province were badly affected. Soil salinity problems were the main concern. Fortunately, due to the humid conditions in the region, salt-polluted arable land has been cleaned by rainfall and irrigation. Recent survey carried out by FAO show that salt deposited in more than two thirds of the affected agricultural land has been leached out already allowing planting to resume with the beginning of the cropping season in April and May. Only approximately 9 thousand ha can no longer be used for farming (China View 31 March 2005).

According to data for 2000 approximately 8 percent of Aceh's output exported to other regions in Indonesia, 26 percent of its output exported abroad, and 66 percent of its output was consumed within the province. Meanwhile, import from other regions in Indonesia and import from abroad were only 6 percent and 4 percent, respectively, of the total material inputs needed for Aceh's production sectors. Therefore, the impact of decline in Aceh's GDP on Indonesia's overall economic performance is expected to be small. The World Bank estimated that GDP growth Indonesia in 2005 would be between 0.1 percent and 0.4 percent lower the pre-tsunami growth forecast (World Bank 2005). LPEM has come up with a slightly higher estimate of growth contraction ( 0.56 percent) (LPEM 2005).

Before the tsunami devastation, the Ministry for the Development of Least Developed Regions had classified 11 districts in Aceh (around 50 percent of the province) as least developed districts. Over the past five years prior to the disaster, Aceh had been experiencing socio-political instability and economic disruption because of the escalation of the 29-year-old secessionist rebellion of the Free Aceh Movement (GAM). About 900 schools had been destroyed or damaged and school attendance had dramatically declined. Meanwhile, health cares had become less accessible because people were afraid 
to visit health facilities for security reason (Soesastro and Ace 2005, World Bank 2005). In 2002, the Indonesian Central Agency of Statistics calculated that around 30 percent of people in Aceh were living below the poverty line. LPEM predicted the percentage of people in Aceh living under poverty line could increase to around 50 percent after the earthquake and tsunami (LPEM 2005). Increase in poverty is probably the most serious economic problem caused by the earthquake and tsunami.

The average rate of inflation in Banda Aceh in January 2005 was 7.02 percent, while for the whole country it was only 1.43 percent. The highest rates of inflation were for processed food and food products - 19.26 percent and 11.24 percent, respectively (compared to national figures of 0.80 percent and 3.11 percent, respectively). House rents are also increasing rapidly. Meanwhile, January 2005 inflation in North Sumatra was around 2.82 percent, with food price increasing by 5.84 percent as the largest contributing factor (CEIC Asia Database, 21 February 2005). There are reports that large presence of donors and NGOs is the main reason for these price increases (in particular increase in housing rent).

\section{(d) Disaster Management}

The government response to a large natural disaster essentially involves three phases: (1) emergency and rescue operations, (2) rehabilitation of basic socio-economic infrastructure, and law and order, and (3) rebuilding the economy and governmental system. Given the peculiar economic and political conditions of Aceh and the sheer magnitude of the devastation and destruction of infrastructure, the first phase of crisis management has taken a much longer time in Indonesia compared to Sri Lanka (see below). The conflict between the Free Aceh Movement and the Indonesian government had adversely affected economic development of the province and severely constrained the dissemination of information on Aceh not only to the rest of the world but also to other parts of Indonesia. Most Indonesians and the world knew how bad the tsunami had hit Aceh only by the 28th of December 2004, while they had news on the impact of tsunami in Sri Lanka and Thailand immediately after the devastation. Furthermore poor 
road network and telecommunication made it difficult to reach many villages along the coast of Aceh to provide emergency rescue activities.

The government embarked on the second phase in April 2005 and this is expected to take around two years. The third phase will involve around five more years. The Indonesian National Planning and Development Agency (Bappenas) has taken initiatives to develop blueprints for the second and third phases. According to estimates prepared by the Asian Development Bank, reconstruction will need US\$1.5 billion in 2005 and up to US\$5 billion over the next five years. The cost of housing rehabilitation/reconstruction alone is estimated at US\$573 million. Funding is expected to come largely from international sources.

International donor response has been remarkably quick and overwhelming. By mid February, approximately 34 countries and various organizations had made pledges and commitments to support various emergency relief, rehabilitation and re-constructions in Aceh and North Sumatra. So far, the total pledges and commitments that specifically targeted to Indonesia has been around US\$ 800 million (Table 2). It is important to note that this figure does not include various soft loans for the reconstruction of Aceh and North Sumatra. For example Australia has agreed to provide soft loans amounting to 500 million AUD throughout the next 5 years. Table 2 also does not include the value of debt moratorium or debt swap offered by several countries such as Germany, France and Italy. In the Consultative Group Meeting for Indonesia (CGI) meeting conducted on the $19^{\text {th }}$ and $20^{\text {th }}$ of January 2005, CGI members agreed to contribute as much as US\$ 1.7 billion in 2005 for the re-construction of Aceh. Of this amount US\$ 1.2 billion will be in the form of grants and the remaining US\$ 0.5 billion in the form of project loans on very soft terms (zero or near zero interest). Of the US\$ 1.2 billion grants, only US\$ 0.2 billion will be distributed through the Indonesian government. The rest will be distributed through non-governmental organizations (Soesastro and Ace, 2005).

Implementation of the second stage of the crisis management process has so far been much slower than proposed in various government policy declarations. Housing 
rehabilitation and resettlement of displaced people; restoration of basic utilities had hardly begun even by mid May 2005, let alone rehabilitation/reconstruction of roads and bridges (ADB 2005, Economist 2005e). Over 90 percent of displaced people were still in rehabilitation camps and/or temporary shelters. Individual agencies were making some progress in resettlement of affected people and clearing roads along the devastated west coast of Aceh, but the central government had not yet come up with a strategy to coordinate these activities. The role of the local (provincial) government is hampered by the loss of so many staff and records. In any case, its capabilities are limited; the army was in de facto control of Aceh for 18 months prior to the disaster as it sought to crush the secessionist rebellion of the Free Aceh Movement (GAM).

The delay in reconstruction has more to do with various institutional and procedural bottlenecks than with the availability of funding. In particular, the government is faced with two major challenges ${ }^{9}$. The first relates to the ownership of the plan for the recovery (or the reconstruction) program. The national government has pointed the Bappenas to be the central agency for developing the recovery planning for the tsunami affected areas in Aceh and North Sumatra. The main challenge for Bappenas is to make all agencies and organizations involved in the reconstruction process feel that they are equal partners/owners of the plan, although it is originally designed by the Bappenas. So far, the dialog between Bappenas and local governments has been rather limited. In the absence of their direct involvement, many local governments feel that they are basically alienated in the reconstruction process which is basically dictated by the central government. Consequently, the local government may want to design their own plan and programs which are incompatible with the Bappenas plan, leading to duplication of activities and inefficient utilization of funds. A related problem is the poor coordination of activities of NGOs and Bappenas. Many NGOs have been resisting going by plans coming exclusively from Bappenas. Currently several consortiums of NGOs are developing their own reconstruction programs. It is not yet clear how they are going to relate these plans to those of Bappenas or local governments.

\footnotetext{
9 Based on discussions with various personals in Bappenas and a discussion in the Indonesia Study Group in the ANU in which Daniel Fitzpatrick was the main speaker.
} 
The Bappenas recovery plan has already begun to face some problems. For instance, displaced people have reacted negatively to a proposal by Bappenas to resettle them in a new housing complex (the tender for which has allegedly been won by a large national construction company). They prefer to go back to their old properties and find some local solutions to rebuild their houses. Although most documents related to property have been lost, people are expecting that there will be a more decentralized mechanism to be able to reclaim their properties. Local governments and NGOs seem to support this will of local people.

The second challenge relates to setting up an institutional mechanism for implementing the reconstruction plan. The national government prefers to establish a new special agency to be the coordinator of the implementation of the recovery activities. Local governments and NGOs are not so eager with this idea, they prefer to have a more decentralized mechanism in implementing the reconstruction of Aceh and some part of North Sumatra that they believe will be able to better accommodate local needs. Clearly a strong coordination among and between governmental and non-governmental organizations is needed so that the implementation of the second and third phase of Aceh and some parts of North Sumatra will be effective and efficient. Otherwise, each organizations will have their own plans and implement them in an add hoc manner.

Another important challenge is to make sure that all or most commitments by international donors will be materialized in a timely manner. As already discussed, some of the commitments may not translate into actual fund flows because of various reasons, which are beyond the control of Indonesia. However, domestic aid absorption capacity also plays an important role. It is vital that the Indonesian government and NGOs join hand in maintaining effective communication with donors, and engage donors in developing projects/programs to minimize the mismatch between donor's interests and reconstruction priorities. 


\section{Sri Lanka}

\section{(a) Historical background}

Unlike Indonesia, Sri Lanka is not a disaster prone country. Floods, and droughts are relatively frequent events, but the causalities have never been more than a few hundreds per event. Historically earthquakes, tsunamis or other seismic disasters have been very rare and far between.

Sri Lanka's local tradition holds that over flow of the ocean occurred several times during the pre-historic times, submerging large areas of the country (Brohier 1934, Part III, Chapter 1). However, the first record of a 'tsunami-like' event ${ }^{10}$ dates back to circa 200 BC (over 2200 ears ago), during the reign of King Kelanitissa in Maya Rata. According to the Mahāwamsa (The Great Chomical of Sri Lanka) mighty waves downed whole villages for miles around and Kelaniya ${ }^{11}$, the seat of Kelanitissa's principality, which lay twenty-five miles from the coast, came within scant four miles (Geiger, 1953, pp 141148). According to Rājāvaliya (An Account of the Kings of Sri Lanka) one hundred paunagams (sea-port towns), nine hundred and seventy fisherman villages - in all, representing eleven-twelfths of the kingdom of Kelaniya, was overrun by sea waves (Suraweera 2000).

Administrative records relating to the Portuguese rule of the coastal provinces of Sri Lanka (1594-1612) mention about an earthquake that struck the city of Colombo on $14^{\text {th }}$ April 1615. The earthquake, which occurred at seven o'clock on the evening of that day, destroyed a portion of the city wall and two hundred houses, killing over two thousand people (10 percent of the total population of the city). Another earthquake occurred in Batticoloa (on the eastern coast of Sri Lanka) on 14 June 1814, causing only some property damages (Wimalaratne 2005).

\footnotetext{
${ }^{10}$ Information provided in the chronicles is not adequate for definitive classification of this vent as a tsunami.

${ }^{11}$ Where the chronicler refers to the present day Keleniya (a citify located about $20 \mathrm{~km}$ southwest of Colombo) or a defunct city in the deep south remains controversial among the Sri Lankan historians.
} 
The tsunami triggered by the eruption of the Krakatoa volcanic island in Indonesia on 27 August 1883 was felt in a number of places on the eastern and southern coast of Sri Lanka. Around 1.30 p.m. that day, the seas receded exposing the seas bed for 20 to 70 fathoms from the shore for few minutes (as it happened during the recent tsunami) but, fortunately, the sea did not return in tidal waves. The waves were only about 4 feet higher than the usual levels. There were only two reported cases of death and was hardly any damage to property (Daily News 2005, Clarke 1957, Winchester 2003). Presumably waves were not so powerful because the location of the volcanic eruption (Indonesian landmass itself provided a cushion against the waves) and presumably the timing of the event; it happened in the month of August when the seas were calmer.

Over the past half a century only two important natural disasters have occurred in Sri Lanka. In November 1978, a cyclone swept across the North-Eastern districts of Amparai, Batticaloa and Polonnariwa. Two thousand people lost lives and nearly a million (7 percent of the total population) became homeless or otherwise affected in this disaster (Albala-Bertrand 1993, Table 3.1). On 17 March 2003, flash floods in the Ratnapura district in South-Central Sri Lanka killed more than 200 people and forced an estimated 150,000 others to evacuate. Most of the victims were killed in a landslide that wiped out an entire village. During 1975-2003, there were only 1700 deaths caused by natural disasters in Sri Lanka. ${ }^{12}$

\section{(b) The 26 December Killer Waves and the Tragic Aftermath}

'When the Hollywood movie 'The Day After Tomorrow' was showing in Colombo last summer, many asked me if such a calamity could befall Sri Lanka. Without debating the scientific merits of the movie, I said that nature always had a few tricks up her sleeve. [However] little did I imagine that before the year ended, killer waves 30 feet high would lash the coast of Sri Lanka, leaving an unprecedented trail of destruction in my adopted country.' (Sir Arthur C. Clarke, 15 January 2005)

\footnotetext{
${ }^{12}$ Based on the Centre for Research on the Epidemiology of Disaster (CRED) Database, Universite Catholique de Luuvin (www.em-dat.net).
} 
The distance between the epicenter of the quake in Sumatra and Sri Lanka is $1500 \mathrm{~km}$. At 8.35am (Sri Lanka Time) (2 hours and 17 minutes after the eruption of the earthquake) the tsunami waves reached Kilinochchi (in Ampara district) in the east of Sri Lanka, and over $2260 \mathrm{~km}$ of coastline in the east and north was hit by the waves within the next fifteen minutes (See Map 2). In many areas, the walls of water were up to 10 meters high when they lashed against the shoreline. In some areas waves did not exactly break, but rather continued inland as a fast stream of high water (like a tidal bloc) swallowing everything in the path; in Mullativu area in North-East Sri Lanka, the sea water column reportedly entered up to $5 \mathrm{~km}$ inland from the coast. Given that there was no history of tsunami in this part of the Indian Ocean and in the absence of an early warning system, the killer waves took the government institutions and people completely by surprise. In many coastal towns and tourists resorts, many people were reported to have watched the prior receding of the sea with curiosity or took the opportunity to collect stranded fish and thus easily succumbed to the waves which came with ferocity within 10 to 15 minutes.

\section{Map 2 about here}

In Sri Lanka, as in the other countries affected by the tsunami, there has been harsh criticism of the failure of the government, in particular the Geological Survey and Mine Bureau (GSMB), to early warning system of the impending disaster. According to the Director of GSMB, ${ }^{13}$ on December 19, a tremor measured less than 3.0 Richter scale was experienced in some parts of the country. The same day he submitted a report on these events to the Ministry of Environment and Natural Resources. On the D-day (26 December), a tremor was felt in most parts of the country around 7.05 in the morning (7 minutes after the earthquake erupted in Sumatra) and the Directors himself felt the tremor and altered the staff. The Pallekele seismological station ${ }^{14}$ transmitted data at $7.06 \mathrm{am}$,

\footnotetext{
${ }^{13}$ This paragraph draws upon an interview the first author had with the Director of GSMB on 5 January 2005.

${ }^{14}$ In the late 1980s, the scientists in the Geological Survey and Mines Bureau (GSMB) of Sri Lanka became aware of some seismic changes in the Indian ocean in the neighbourhood of Sri Lanka. There was evidence that the Indo-Australian plate had been splitting over a short geological time, making Sri Lanka vulnerable to seismic activities. GSMB therefore took initiatives to establish a seismic monitoring system
} 
but in the absence of data analysing capabilities, the GSMB staff had to wait for the information from the USGS. This information arrived only around $10 \mathrm{am}$, when the killer waved had already done the job. In theory, given that it took more than two hours for the tsunami to reach the shores of Sri Lanka, timely arrival of information would have saved many lives. However, there is ample evidence from large natural disasters in other countries that warning processes make no sense in the absence of disaster preparedness as a well-rooted social arrangement (Albala-Bertrand 1993, Haque 2003).

The 26 December tsunami is by far the most devastating natural catastrophe in the recorded history of Sri Lanka. As of 25 February the 'official' death toll stood at 30,980 with 6,300 reported as missing (most portably dead) (Table 8). It is important to note that the official figures do not cover the death toll in coastal areas under the control of Liberation Tigers of the Tamil Elam (LTTE) that stretch from Nagakovil in the North down to Alampili in the district of Ampara. ${ }^{15}$ This segment of the coastal belt was the worst affected by the tsunami (see Map 2). Based on anecdotal evidence from LTTE source, Noyalhr (2005) has estimated the unrecorded death toll in this area to be between 32 to 35 thousands. Women and children accounted for two thirds of the death toll, confirming patterns observed in various natural disasters in other parts of the world. The number of children who lost both of their apparent amounted to 1,060, while 3,414 children have lost one parent. Around 600 foreign tourists were among the dead.

\section{Table 8 about here}

According to official estimates 443,000 people (approximately 2.4 percent of the total population the country) were displaced and between one to two million (10.5 percent) were directly affected by the disaster. The North East coastal belt of the country was the

\footnotetext{
was set up in Pallekele (near Kandy) in 1999 with financial and technical support from the Scripps Institute of Oceanology of the University of California and the US Geological Survey (USGS). The centre, which became operational in 2001, provided for recording seismic information and transmitting them to USGS through the head office of GSMB in Colombo (GSMB 1992). Since the GSMB did not have capacity to analyze the data, it had to rely on USGS for the activity reports.

15 The LTTE is a secessionist rebel organisation that has been fitting for an independent homeland (Elam) for the ethnic Tamil community in Sri Lanka. For details on the LTTE and the ethnic conflict in Sri Lanka, see various contributions in Rotberg (1999)
} 
worst affected. The percentage of coastal population affected ranges from an estimated 35 percent in Kilinochi to 80 percent in Mutative and 78 percent in Asmara coastal divisions compared to the southern districts of Galle, Matara and Hambantotata where less than 20 percent of the population was affected, albeit with scattered pockets of severe damaged (ADB, JBIC and World Bank 2005). The tsunami waves largely missed major urban areas and important industrial assets. Port of Colombo and its infrastructure was not affected, apart from some minor damages to a few container ships.

One notable surprise that came out of the tsunami disaster was the power of 'animal spirit'. The Yala National Park located in the south-eastern coast of Sri Lanka was one of the areas badly hit by the killer waves. Over two hundred bodies of tourists and locals were found in the park during rescue operations, but wildlife officials were unable to find the body of a single animal (Sunday Leader (Colombo), 2 January 2005, 23). This evidence is consistent with the emerging view among the seismologists that the study of animal behaviour in a systematic way (in combination with other ancillary data) could provide useful early warning of an impending natural disaster.

The disaster holds important lessons in the area of coastal resource management (Clarke 2005). Since the beginning of the 20th century, there has been a rule that regulates any construction within 300 meters of the shore. For a long time, this rule has been ignored or openly flouted by individuals as well as hotel developers and shrimp farmers. Moreover, there has been gross violation of regulations prohibiting mining coral reefs and destroying coastal mangrove forests, which act as splendid bulwarks against the wrath of the sea. Mining was not the only threat to the reef. Fishermen use dynamite to stun and catch fish, blowing up everything for meters around. This illegal activity has continued over the years, wrecking the reef. There is clear evidence that thousands of lives could have been saved if the right action had been taken at the right time to enforce these regulations; the damage has been much greater in areas where the incidence of violation of environmental regulations was greater (Clarke 2005). In the aftermath of the tsunami, environmentalists and divers from across South and Southeast Asia have reported similar examples. For instance, mangroves in southern India’s Pitchavaram and Muthupet regions acted like a shield and bore the brunt of the tsunami, protecting around 
1700 people living in hamlets built inside between 100 to 1000 meters from the mangroves (www.fao.org/newsroom/en/news/2005/89119). As already noted, the death toll in the island of Simeuleu in Indonesia was relatively low, partly due to mangrove forests that surrounded the island. By contrast, uprooting or snapping off at mid-trunk of mangroves caused extensive property damage in Thailand. ${ }^{16}$

\section{(c) Economic impact}

The overall damage to the economy has been estimated at around US\$ 1 billion (4.5 percent of GDP). ${ }^{17}$ Total financial needs for reconstruction are estimated to be around US\$1.5 to 1.6 billion (Table 9).

\section{Table 9 about here}

The immediate effect of the disaster on growth performance of the economy is likely to be small mainly because the destruction was largely confined to the southern and eastern provinces. The Central Bank is predicting that GDP growth will drop from a predicted 6 percent to around 5.5 percent in 2005. The IMF and the ADB have however cut their growth forecast for 2005 by a greater magnitude, from 5 percent to 4 percent, and 5.6 percent to 4.2 percent respectively. These estimates are based on the available estimates of the direct contribution of the affected regions to the overall national output of the economy. These output losses are likely to be offset to a considerable extent by higher investment growth as reconstruction of the physical capital stock in effected areas commence. A sharp pick up in fixed investment growth (18 percent compared to a pretsunami forecast of 8.5 percent) and a modest increase in government consumption is predicted in 2005 (ADB, JBIC and World Bank 2005).

Tourism and fishing, the two main economic sectors of the tsunami affected areas, have suffered massively. These sectors accounted for only 2.2 percent and 1.7 percent of GDP in 2003. More than 80 percent of the Island's fishing fleet was wiped out and more than 14,000 fishermen were killed by the tsunami. Approximately 30 percent of the room

${ }^{16}$ www.fao.org/newsroom/en/news/2005/89119 
capacity of tourist hotel was damaged. The tourist industry, with approximately 30 percent of room capacity damaged, will take some time to recover. About three forth of the rooms were back in operation by the end of February, but a sharp drop in occupancy levels is expected because of inadequate infrastructure. Among other economic activities, even in the coastal areas of Ampara and Baticcaloa, the rice crop was not badly affected. However, heavy loss of life along the coastal belt would lead to severe manpower shortages that could impede harvesting operations. There will be adverse implications for insurance and banking industry. The industry's profitability for 2005 is likely to be materially impaired on account of potential write-offs and provisions against bad loans that would arise as a result of the damage. Although loans extended to the affected regions amount only to between 5 percent to 10 percent of total loans in the case of the large banks. However, loss to the banks on account of directly affected borrowers would be significant given the significant damage to underlying collaterals such as real state and stocks in trade which would have normally mitigated the losses of faced by the banks. The non-bank financial sector, comprising of leasing companies and finance companies, As with banks, the exposure of non-bank financial institutions to the affected areas is low, but losses on affected borrowers could be high, as vehicles in Sri Lanka were typically not covered for perils such as tsunamis or earthquakes.

According to estimates by the IMF the current account deficit of Sri Lanka would widened from US\$2.28 billion in 2004 to US\$ 2.69 billion in 2005. Although major export sector - textiles and garments - have not been affected, tourism earnings (which account for about 7 percent of total current account receipts) were expected to fall by about 15 percent compared to 2004. Imports related to reconstruction activities are expected be reflected in 3 percent increase in the import bill. However, the aid inflows (provided of course the pledges are honored by the donor countries) would be more than sufficient to counterbalance these adverse developments and to generate a modest overall surplus in the balance of payments.

${ }^{17}$ These figures do not cover assets losses in the informal sector. 
The indications are that adverse economic impact of the disaster will result in a significant increase in the incidence of poverty. The affected provinces (South and South East) contribute to about 17.5 percent of GDP but account for a larger proportion of the population (26 percent). The per capital GDP in these provinces is estimated at about US\$640, compared to the national average of US\$930 and about US\$1500 in the Western province. Moreover, in the affected regions vulnerable groups, such as fishermen living close to the shore in simple houses and shelters and those who make a living by engaging in informal sector activities evolved around tourism have borne the brunt of the negative impact, in conformity with universal patterns of 'the life and death arithmetics' of disasters world over (Sachs 2005). The ADB predicts that the tsunami’s immediate and lingering effects would throw some 250,000 people below the poverty line. This implies an increase in the overall head-count rate of poverty in Sri Lanka from the present level of 22.7 percent (World Bank 2004) to 25 percent.

\section{(c) Disaster management}

The first phase of disaster management has gone smoothly. At the beginning, there was fear that the outbreak of disease could cause significant economic disruption. This fear never materialized (WHO 2005). No outbreaks of epidemics or unusual cluster of communicable diseases has been reported, other than a few sporadic cases of diarrhea and acute respiratory infections. There is little evidence about problems related to rescue operations in the areas controlled by the Liberation Tigers of Tamil Elam (LTTE). Rescue missions returning from the area, however, attested to the effectiveness of the organized response initiated by the LTTE immediately after the tsunami hit the coastline under their control. As other grass-root political organizations, LTTE has well organized structures, mechanisms and trained personnel to respond to humanitarian emergencies.

At the time of the tsunami, macroeconomic conditions of the economy were precarious. The government was running a budget deficit of over 8 percent of GDP. ${ }^{18}$ Public debts amounted to over 100 percent of GDP. The newly elected government was relying predominantly on the Central Bank (printing money) to implement its costly election

\footnotetext{
${ }^{18}$ Data reported in this paragraph are from Central Bank of Sri Lanka, Annual Report (various issues).
} 
promises. On the external front, external debt stock amounted to US\$11bn (57 percent of 2004 GDP). The oil price escalation had resulted in a widening of the current account deficit from 3 percent of GDP in 2003 to 3.7 percent in 2004. The debt service ratio had remained in the range of $13.2-15.2$ percent cent for the past five years. Public external debt service payments accented for over two thirds of total debt service payments of the country by the 2004. The IMF and the World Bank had suspended some of the previously approved credit line pending the demonstration of its economic credentials by the new government which had come into power by promising to implement a 'national development policy' without relying on the Bretton Woods institutions. Under these circumstance, there was little degree of freedom for the government to manage the unanticipated devastation and rebuilt the economy on its own.

The response of the international community was swift and remarkable. Total aid pledges to Sri Lanka had passed the 1.5 billion mark by mid-January, exceeding the amount of the tentative reconstruction budget. In addition, on January 13, the IMF approved the granting to Sri Lanka of a freeze on repayments in 2005 of some 113.5 million dollars in debt. The IMF also provided Sri Lanka with access to emergency funding totaling 160 million dollars. The ADB allocated a sum of US\$200 million for Sri Lanka for rehabilitation work. Debt rescheduling by the Paris Club donors also strengthened both the government financial position and the external payment position because government debts accounted for the bulk of total external debts of the country.

Notwithstanding the improved financial position of the country, the task of disaster management has become more complex when it moved beyond the immediate, humanitarian rescue/relief stage into the reconstruction/rebuilding stage. It remains to be seen whether the government can overcome its usual very slow pace in project implementation; for the past decade or so the annual rare of absorption of foreign aid in Sri Lanka has varied in the range of 40 percent to 45 percent. So far the progress has been rather slow. By mid-May, more than 75 percent of the displaced people were still living in rehabilitation camps and/or with friends and relatives. Unlike in Aceh, there has been rapid progress in clearing major roads and restoring public utilities. However, 
the major reconstruction/rebuilding projects were still at the planning stage (ADB 2005). The rescue/rehabilitation phase has gone smoothly because the objectives were straight forward and individuals co-operative behaviour did not leave much room for ideological differences. However, unfortunately domestic politics has come to the fore in the reconstruction process, which essentially involves multiple objectives and conflicts of interests in resource allocation. Delay in government action had begun to act as a major deterrent to rehabilitation and reconstruction carried out by affected individuals themselves, NGOs and other civil-society organizations.

The proposed regulations for reconstruction (to be implemented through the Urban Development Authority and the Coast Conservation Department) include a ban on the construction of dwellings within 100 meters from the beach. Implementation of this coastal buffer zone legislation has already come under pressure. The displaced fishermen who were previously living within the zone demand that they be given houses built on the immediate adjacent stretch of land. Their worry is the safety of their boats and easy access to the sea. The hotel industry is concerned about the adverse implications of the buffer zone on its construction plans; over 10 beach hotel projects in the South West Coast worth US\$ 30 million are said to be on hold due to this restriction. The buffer zone proposal soon turned out to be a major stumbling book in the implementation of the resettlement program as the major opposition party (the United National Party) sided with the protestors.

The role of government in the resettlement of affected families has become a controversial issue. The UNP is of the view that the rehabilitation initiatives should be aimed at putting resources into peoples hands and letting them decide how best to proceed. However, the government is planning to play a major role in the reconstruction of house for the displaced people for two main reasons. First, this would enable effective implementation of the buffer zone legislation. Secondly, many displaced families (in particular, those living in more densely populated affected areas) do not have clear titles to their land, a problem which has become enormously complicated by the large loss of 
life in these areas. For many of these families, it will be difficult to rebuild on their own, even if funds are made readily available.

It is important to bear in mind that the tsunami disaster occurred in Sri Lanka against the backdrop of a long-standing ethno-political conflict and the and at a time when the negotiation process to end it though political means was under severe stress. Disaster management in Sri Lanka, therefore, involves interesting and possibly unsettling political dimensions. In the wake of the disaster, there were hopes among policy/political circles that the tsunami devastation it would present an opportunity for cooperation between the government and the LTTE. This was particularly so because much of the devastation took place in the Eastern province, the power base of the LTTE. The tsunami destroyed the bulk of assets and personnel of the LTTE navel force (The Sea Tigers) and, in relative terms, the overall death toll and economic destruction was much larger in the LTTEdominated east, compared to the rest of the country. However, these hopes were soon dashed as the government and the international aid community failed to draw up a conflict-sensitive disaster management strategy involving the LTTE as an equal partner. ${ }^{19}$ The government soon came under accusation by the LTTE (as well as the Muslim community in the East) of overly focusing it relief efforts in the south of the country (where the majority Sinhalese population live). The LTTE sees the Eastern provinces as the territory under its control, and naturally would not like to see the government improving its popularity among the local population. The success of reconstruction process depends crucially on the ability of the government to ensure that its fragile relations with the LTTE do not erupt into renewed conflict.

The ability of the government to get the LTTE involved as an equal partner in the rehabilitation and reconstruction process has been severely constrained by it weak power base. The People's Alliance (PA) government of Chandrika Kumaranatunga is a loose coalition of seven parties of varying political shade. The 'Marxist-nationalist' Janatha Vimukthi Peramuna (JVP), the largest ally of Kumaranatunga’s party (Sri Lanka

\footnotetext{
${ }^{19}$ The government lost an important opportunity for reconciliation when Kofi Annan, who visited Sri Lanka in early January, was refused permission to visit LTTE-held areas.
} 
Freedom Party, SPF) in the coalition is a strong opponent of any form of devolution of power to the LTTE. The JVP has set up its own relief fund and has seemingly strengthen its tradition support base in the south of the country thorough highly efficient, grass-rootlevel rescue/rehabilitation work in the aftermaths of the tsunami. Recently, it threatened to topple the government in the event of any move by the President in favour of accommodating LTTE demands. To make matters worse, relations between the administration of Kumaranatunga and the opposition United national Party (UNP) have been very poor in recent months. The relations seem to have further weakened after President Kumaranatunga’s off-the-cup statement in mid February (which she subsequently withdrew) that, for the sake of smooth implementation of the reconstruction program, she would remain in power for five more years.

As the reconstruction process involves massive investment in non-tradable activities, allocation of government funds need to be managed carefully to avoid jeopardizing macroeconomic instability. Macroeconomic management in the reconstruction phase become even more complicated when a country rely on massive aid inflows to finance these activities. With massive capital inflows the possibility of an appreciation of the real exchange rate with adverse implications for the traded goods sectors (export producing and import competing sectors) of the economy cannot be ruled, out unless the inflow of capital in managed in an orderly fashion.

The exchange rate of the Sri Lanka Rupee (SLR) (which has been under a highly flexible, managed floating regime since 2001) began to appreciate as aid commitments began to mount, even before substantial about of these pledges begun to translate into actual inflows. The SKL/US\$ rate which stood at 105 on 20 December 2004 declined persistently to about 95 by mid-January (Figure 2). Initially the Central Bank resisted foreign exchange market intervention despite recurrent demand by the exporters. However, from about the third week of January it has begun to 'lean against the wind' to stabilize the exchange rate. It seems that the Central bank intervention has been useful in stabilizing the currency in nominal terms; from about the late February it has lightly recovered and remained in the narrow range of 99.3 to 99.7. However, it is too early to 
assess the implications of capital inflows for the movement of the real exchange rate. There would be pressure for the real exchange appreciation when the expenditure effects of the reconstruction process begin to impact on domestic non-tradable prices. On the other hand, the actual aid flows may fall short of the initial pledges, defying the initial optimism of the foreign exchange market participants and reducing this pressure. There are two main reasons for a shortfall of actual aid flows from the amount of total pledges. First, evident from previous humanitarian crises suggests that some of the pledges simply take the form of 'face-saving' commitments, which simply lead to subsequent reshuffling of the aid portfolio while keeping total aid to the given country by an large unchanged. Second, even if we consider all pledges as genuine, whether they would be translated into actual aid flows depends crucially on the aid absorption capacity of the given country.

\section{Figure 2 about here}

\section{Concluding Remarks}

A simple but important lesson from the experience in Sri Lanka and Indonesia (and the other tsunami-affected countries in the region) in the 26 December tsunami disaster is the need to educate the population about simple precautions that would save lives during tsunami (and other national disasters). For instance clear prior understanding by the public of a receding sea as an early warning of impending killer waves would have saved thousands of lives. The case for improving public awareness an integral part of the school education system is particularly strong in Indonesia where, according to the information harnessed in this paper, both the frequency and the severity of natural disasters has been on the increase over time.

The tsunami disaster holds important lessons in the area of coastal resource management. There is evidence that thousands of lives could have been saved if the right action had been taken at the right time to enforce environmental regulations to perverse coral reefs and mangroves, which effectively act as a buffer against killer waves. There is a clear need for systematic analysis of the link between violation of environmental regulation 
and the severity of the destruction caused by the killer waves in Sri Lanka, Indonesia and other tsunami-affected countries in order to drive home this message.

An immediate reaction to the tsunami calamity has been to call for action by individual countries as well as at the regional level to set up early warning systems. This is proposition certainly deserves serious attention. However, to be effective any early warning system needs to be implemented as part of a carefully designed disaster management program. As the Sri Lankan experience with the seismic monitoring centre established with the assistance of the University of California and the US Geological Survey vividly demonstrated the mere acquisition of hardware would not do the job. Scientists to operate the system need to be trained and there has to be a firm political commitment for the smooth implementation of the project. More importantly, there is ample evidence coming from disaster situations in other countries that disaster prediction make no sense in the absence of disaster preparedness as a social arrangement, achieved, among other means, through proper education and training and though an extensive media campaign.

The evidence from Indonesia and Sri Lanka reconfirms evidence coming from previous disaster situations in other countries that the poor bear the brunt of the calamity. This evidence makes a strong case for placing emphasis on policies and programs for cushioning the poor against natural disaster as an integral part of national development strategy. For disaster prone countries such as Indonesia, there is a clear need for setting up an institutional mechanism, backed by a central disaster management fund, with capacity to engage swiftly in rescue and initial rehabilitation operations following a disaster. To be effective such institutional mechanisms/procedures could be developed in such a way as to maintain operational links with national and international NGOs, other charitable organizations and various UN organizations involved in disaster management.

The Sri Lankan and Indonesian disaster management records over the past five months clearly demonstrate that mere availability of funds does not guarantee speedy implementations of reconstruction/rebuilding programs. Effective absorption of aid 
depends crucially on the ability of the authorities of the affected country to engage local communities, local governments, NGOs and international donor agencies both in the planning and implementation processes. This is going to be a daunting task particularly if the disaster occurs in a country/area suffering from a deep-rooted ethno-political conflict such as Aceh and east Sri Lanka. Jading by the experiences of various disaster situations in other countries, some of the commitments may not translate into actual fund flows because of various reasons beyond the control of the affected country. Nevertheless, engaging donors in developing projects/programs to minimize the mismatch between donor's interests and reconstruction priorities is vital for maximizing national gains from the generosity of international donors. The international donor community also should give serious consideration to designing innovative strategies for improving aid effectiveness in specific disaster situations.

Finally, Sri Lanka's post-tsunami experience seems to hold important lessons for macroeconomic management in the reconstruction phase when the disaster-affected country relies on massive aid inflows. With massive capital inflows, there is the possibility of exchange rate appreciation with adverse implications for the traded goods sectors (export producing and import competing sectors), unless the inflow of capital in managed in an orderly fashion.

\section{References}

Abbott., Patrick L. 2004. Natural Disasters ( $4^{\text {th }}$ edn.), New York: McGraw Hill.

Albala-Bertrand, J.M. 1993. Political Economy of Large Natural Disasters, Oxford: Clarendon Press.

ADB (Asian Development Bank). 2005). ADB Review, Special Issue: Rebuilding Lives after the Tsunami, April. (www.adb.org/review).

ADB (Asian development Bank), JBIC (Japan Bank for International Cooperation and the World Bank .2005. Sri Lanka 2005 Pot-Tsunami Program: Preliminary Damage and Need Assessment, Colombo: World Bank Office. 
Applegate, G., R. Smith, J.J. Fox, A. Mitchell, D. Packham, N. Tapper, and G. Baines. 2002. "Forest Fire in Indonesia: Impacts and Solutions." In C.J.P. Colfer and I.A.P. Resosudarmo (eds), Which Way Forward? People, Forests and Policymaking in Indonesia. Washington DC: Resources for the Future.

Bakonas PBP (Indonesian Emergency Relief Coordination Agency. 2005. Buletin Bakonas PBP. 14 March, Jakarta.

Bergen, M.J.van, A. Bernard, S. Sumarti, T. Sriwana, and K. Sitorus. 2000. Creater Lakes of Java: Dieng, Kelud and Ijen. Excursion Guidebook, International Association of Volcanology and Chemistry of the Earth's Interior (IAVCEI) General Assembly, Bali, July 17-22.

Brohier, R.L. .1934. Ancient Irrigation Works in Ceylon, Colombo: Government Press.

Chandler, Clay .2005. A wave of Corporate Charity’, Fortune, January 24, 17-18.

China View. 2005. Tsunami Causes Limited Soil Salinity Problems: FAO. March, 31. http://news.xinhuanet.com/english/2005-03/31/content_2767545.htm (latest visit was 01/04/2005)

Clarke, Author C. 1957. The Reefs of Taprobane, Peguin.

Clarke, Sir Arthur C. 2005). The Day After Tsunami: New Waves of Human Spirit and Perseverance in Sri Lanka', Daily Mirror (Colombo), January 15.

CRED (Centre for Research on the Epidemiology of Disasters). 2005. EM-DAT: The OFDA/CRED International Disaster Database. http://www.em-dat.net/who.htm. (latest visit was 14/02/2005)

Cuny, Frederick C. 1983. Disasters and Development, New York: Oxford University Press.

Daily News .2005. Ceylon had its First Tsunami Experience in 1883 (reproduction of excerpts from The Ceylon Observer (Colombo), August 27, 1883), 21 February.

Deutsche Presse-Agenture. 2005. Governments not Interested in Warning System. January, 4. http://www.taipeitimes.com/News/edit/archives/2005/01/04/2003217997 (latest visit was 01/04/2005)

Economists. 2005a. 'The Cruel Sea (special report on Asia’s Tsunami), 1 January 2005, 15-17.

Economists. 2005b. 'The Tsunami: After the Deluge’, 8 January 2005, 23-27 
Economists. 2005c. 'After the Tsunami: The Forgotten People’, 22 January, 32.

Economists. 2005d. 'After the Tsunami: Rebuilding Starts’, 5 February, 28.

Economist. 2005e. 'After the Tsunami: Too Slow in Aceh’, 26 March, 28-29.

EIU (Economist Intelligence Unit), 2005. Asia’s Tsunami: The Impact, London: EIU.

FAO (Food and Agricultural Organization). 2005. Impact of the Tsunami on Fisheries, Aquaculture and Coastal Lives, 7 January, FTP.FAO.org/FI/Document/tsunami

Furneaux, R. 1964. Krakatoa, London: Secker \& Warburg.

Geiger, Wilhelm (Translator/editor). 1953. The Mahāvansa (or The Great Chronicle of Sri Lanka) translated into English by Wilhelm Geiger), Colombo: Government Publication Bureaus

Glover, David and Timothy Jessup (eds.). 1999. Indonesia's Fire and Haze: The Cost of Catastrophe. Singapore: Institute of Southeast Asian Studies.

Gunatilake, Ananda. 2005. Earthquakes and Tsunami: Causes, Effect and Lessons, The Island (Colombo), 4 January.

Haque, C. Emdad. 2003. Perspective of Natural Disasters in East and South Asia, and the Pacific Island States: Socio-economic Correlates and Need Assessment. Natural Hazards, 29, 465-483.

Hirshleifer, Jack.1993. Disaster and Recovery, in David R. Henderson (ed.) The Fortune Encyclopedia of Economics,

Jayawardena, Dulip. 2005. Mitigating the Hazards of the Tsunami. Daily Mirror (Colombo), 9 January.

Kompas. 2005. Simeulue Ternyata Belum Tersentuh. April, 01. http://www.kompas.com/kompas-cetak/0504/01/UTAMA/1656882.htm (latest visit was 01/04/2005).

Lay, Thore, Hiro Kanamori and Charles Ammon. 2005. The Great Sumatra-Andaman Earthquake of 26 December 2004. Science, 308, 1127-1139.

LPEM (Institute for Economics and Social Research). 2005. Perhitungan Kebutuhan Dana Pembangunan kembali Aceh. LPEM Internal Report, Jakarta.

National Geographic. 2005. Geographica Special: Tsunami - Where Next?, April.

NGDC (National Geophysical Data Center). 2004. Tsunami events in the Indian Ocean Region. http://www.ngdc.noaa.gov/seg/hazard/tsu.shtml. 
Noyalhr, Keith. 2005. Death Toll much higher than Government Figure. Daily Mirror ( Colombo), January 15.

Rotberg, Robert I. 1999. Creating Peace in Sri Lanka: Civil War and Reconciliation, Washington DC: Brooking Institution Press.

Sachs, Jeffrey. 2005, The Class System of Catastrophe. Time, January 10, 86.

Soehaimi, A., E.K. Kertapati, Surono, Supartoyo, and J.H. Setiawan. 2005. Gempa Bumi dan Tsunami NAD-SUMUT 26 Desember 2004. Paper presented in the GeoSeminar, 14 January, Pusat Penelitian and Pengembangan Geologi, Bandung.

Soesastro Hadi and Raymond Ace. 2005. Survey of Recent Development. Bulletin of Indonesia Economic Studies, 41(1), 5-34.

Suraweera, A.V. (Editor/translator). 2000. Rajavalia: A Comprehensive Account of the Kings of Sri Lanka, Ratmalana: Vishwa Lekha.

Tomascik, T., A.J. Mah, A. Nontji, and M.K. Moosa. 1997. The Ecology of the Indonesian Seas: Part One. Singapore: Periplus Editions.

ECLAC (United Nations Economic Commission for Latin America and the Caribbean) .2003. Handbook for the Evaluation of the Socioeconomic and Environmental Impact of Disaster (LC/MEX/G.5), Santiago, ECLAC, July 2003)

USGS (United States Geological Survey). 2003. Description: Indonesian Volcanoes and Volcanics. http://vulcan.wr.usgs.gov/Volcanoes/Indonesia/description_ indonesia_volcanics.html. (latest visit was 08/02/2005)

USGS (United States Geological Survey). 2004. Earthquakes with 1,000 or More Deaths from 1990. http://neic.usgs.gov/neis/eqlists/eqsmajr.html. (latest visit was $08 / 02 / 2005)$

Wetlands International-Indonesia Programme. 2005. Tsunami of Aceh and North Sumatra 26 December 2004. http://www.wetlands.or.id/ (latest visit on 30/03/2005)

Wheeler, M.C. 2002. Climate Variability on Multiple Time Scales: Monsoon Bursts and El Nino Clash over SE Asia. Paper presented in the International Science Roundtable for the Media, Bali, 4 June.

WHO (World Health Organization). 2005. Tsunami \& Health Situation Report \# 26 (28 March) (www.who.int) 
Wimalaratne, K.D.G. 2005. Tsunami and Earthquakes in Sri Lanka: The Role of the Historian, Daily News (Colombo), 20 February.

Winchester, Simon. 2003. Krakatoa: The Day the World Exploded 27 August 1883. London: Penguin Books Ltd.

World Bank. 2004. (to be completed)

World Bank. 2005. Indonesia: Preliminary Damage and Loss Assessment: The December 26, 2004 Natural Disaster. www. Worldbank.org. 
Table 1: The Tsunami Devastation: Summary data (circa end of February 2005)

\begin{tabular}{|c|c|c|c|c|c|}
\hline & Areas affected & Damage & Displaced & Deaths & Missing people \\
\hline India & $\begin{array}{l}2200 \mathrm{~km} \text { of coastal } \\
\text { land; } 300 \mathrm{~m} \text { to } 3 \mathrm{~km} \\
\text { inland and } 3 \text { million } \\
\text { people }\end{array}$ & $\begin{array}{l}897 \text { villages, } 157,393 \text { dwelling units, } \\
11,827 \text { ha of cropped area, } \\
\text { US } \$ 1.56 \text { bn assets }\end{array}$ & 647,556 & 10872 & 5551 \\
\hline Indonesia & $\begin{array}{l}\text { Aceh, } 14 \text { out of } 21 \\
\text { districts; } 1 \text { million } \\
\text { people }\end{array}$ & $\begin{array}{l}172 \text { sub-districts, } 1550 \text { villages, and } \\
21659 \text { houses }\end{array}$ & 811409 & 166,760 & 127,749 \\
\hline Malaysia & $\begin{array}{l}\text { North West states of } \\
\text { Penang and Kedah }\end{array}$ & & 8000 & 68 & 6 \\
\hline Maldives & 20 attols & 100000 people & 10578 & 82 & 26 \\
\hline Myanmar & 23 villages & 592 houses of 17 villages & 2591 & $\begin{array}{l}\text { At least } \\
2500 *\end{array}$ & --- \\
\hline Sri Lanka & $\begin{array}{l}\text { 1720km of coastal } \\
\text { land; } 300 \mathrm{~m} \text { to } 3 . \mathrm{km} \\
\text { inland, } 103 \text { families. }\end{array}$ & $\begin{array}{l}\text { 78,529 fully damaged houses; } 41097 \\
\text { partly damaged houses }\end{array}$ & 502668 & 30959 & 5644 \\
\hline Thailand & $\begin{array}{l}6 \text { provinces on the } \\
\text { west coast }\end{array}$ & $\begin{array}{l}\text { 6.85m baht have been provided to } \\
\text { assist victims }\end{array}$ & --- & 5392 & 3100 \\
\hline Somalia & $\begin{array}{l}\text { Puntland region worst } \\
\text { hit, } 650 \mathrm{~km} \text { coast line }\end{array}$ & $\begin{array}{l}600 \text { families have lost properties. } \\
2600 \text { fishing boats destroyed }\end{array}$ & 4000 & $\begin{array}{l}\text { At least } \\
150\end{array}$ & NA \\
\hline
\end{tabular}

Source: WTO (2005) and Economist (2005c) (for data on deaths in Myanmar).

Note:

* Estimated deaths in Phang Nga province, which took the biggest hit on $26^{\text {th }}$ December, 2004. 
Table 2: Aid Commitments to Tsunami Affected Countries, as of 21-February 2005 (US\$ million) ${ }^{1}$

\begin{tabular}{|c|c|c|c|c|c|c|c|c|c|c|}
\hline & India & Indonesia & Sri Lanka & Thailand & Myanmar & Maldives & Malaysia & Somalia & Multilateral & Total \\
\hline Australia & & 399.3 & 2.4 & & & & & & 29 & 430.7 \\
\hline Austria & & & & & & & & & 69.2 & 69.2 \\
\hline Belgium & & 2.3 & 2.3 & & & 0.08 & & & 11.5 & 16.2 \\
\hline Brunei Darussalam & & & & & & & & & 3.7 & 3.7 \\
\hline Canada & & 2.3 & 0.4 & & & 1.9 & & & 346.2 & 350.8 \\
\hline China & & 0.7 & 1 & & 0.2 & 0.1 & & & 62.2 & 64.2 \\
\hline Czech Republic & & 0.2 & 0.5 & & & & & & 9.9 & 10.6 \\
\hline Denmark & 0.1 & 13.5 & 11.1 & & & 0.02 & 0.03 & & 53.3 & 78 \\
\hline Finland & & 1.4 & & & & & & & 67.8 & 69.2 \\
\hline France & & 1.8 & 0.8 & & & 0.03 & & & 440.1 & 442.7 \\
\hline Germany & 0.8 & 19.2 & 20.8 & & & 1.3 & & 0.1 & 624.1 & 666.3 \\
\hline Greece & & 10.1 & 7.5 & 0.6 & & 0.7 & & & 7.6 & 26.5 \\
\hline Iran & & & & & & & & & 5 & 5 \\
\hline Ireland & 1.2 & 0.4 & 1.3 & 0.03 & & & & & 10.4 & 13.3 \\
\hline Italy & & 4.3 & 14.5 & & & & & & 94.1 & 112.9 \\
\hline Japan & & 200.5 & 101.7 & 0.1 & & 25.4 & & & 173.6 & 501.3 \\
\hline Korea (Republic of) & & 0.5 & 0.4 & 0.1 & & 0.05 & 0.05 & & 49.5 & 50.6 \\
\hline Kuwait & & & & & & & & & 100 & 100 \\
\hline Luxemburg & & & 0.4 & & & & & & 6.5 & 6.9 \\
\hline Malaysia & 0.5 & 3.4 & 0.5 & & & 0.1 & & & 1.3 & 5.8 \\
\hline Malta & & & 10.9 & & & & & & & 10.9 \\
\hline Netherlands & & 14.3 & 8.7 & & & & & & 243.6 & 266.6 \\
\hline New Zealand & & 14.7 & 0.3 & & & 2.9 & 0.03 & & 27.6 & 45.5 \\
\hline Norway & 0.3 & 8.6 & 6.9 & 0.01 & & 0.2 & & 1.7 & 154.7 & 172.4 \\
\hline
\end{tabular}




\begin{tabular}{|c|c|c|c|c|c|c|c|c|c|c|}
\hline Portugal & & 5.6 & 4.4 & 0.02 & & & & & 6.2 & $\mid 16.2$ \\
\hline Qatar & & & & & & & & & 25 & 25 \\
\hline Russian Federation & & & & & & & & & 32.2 & 32.2 \\
\hline \begin{tabular}{|l|} 
Saudi Arabia (Kingdom \\
of)
\end{tabular} & 0.2 & 2.5 & 1.5 & 1 & & 0.7 & & 0.1 & 157.5 & 163.5 \\
\hline Singapore & & & & & & & & & 13.7 & 13.7 \\
\hline Spain & & & 1.3 & & & & & & 70.3 & 71.6 \\
\hline Sweden & 0.7 & 7.5 & 2.3 & 0.05 & & & & 0.3 & 66 & 76.9 \\
\hline Switzerland & 0.4 & 15.5 & 8.9 & 1 & & 0.1 & & & 17.9 & 43.8 \\
\hline Turkey & & 2.9 & 1.3 & 0.5 & 0.06 & 0.3 & 0.3 & 0.1 & 0 & 5.5 \\
\hline UK & 2.7 & 21.5 & 9.6 & & & 1 & & 1 & 84.4 & 120.2 \\
\hline US & 4.1 & 38.2 & 62.4 & 0.3 & & 1.6 & 0.05 & 1 & 245.7 & 353.4 \\
\hline Other countries & 0.1 & 0.6 & 0.3 & 0.1 & 0 & 0 & 0 & 0 & 4.3 & 30.1 \\
\hline Organization & & 16.55 & 11.4 & 0.05 & 0 & 2.8 & 0.05 & 0 & 1726.3 & 1757.2 \\
\hline FAO & & 0.4 & 0.4 & & & 0.3 & & & 0.4 & 1.5 \\
\hline UNDP & & & & & & & & & 2.3 & 2.3 \\
\hline UNEP & & & & & & & & & 1 & 1 \\
\hline American Red Cross & & & & & & & & & 50 & 50 \\
\hline Arab Gulf Fund & & & & & & & & & 0.1 & 0.1 \\
\hline Asian Development Bank & & & & & & & & & 600 & 600 \\
\hline \begin{tabular}{|l} 
Disasters Emergency \\
Committee (UK)
\end{tabular} & & & & & & & & & 191.6 & 191.6 \\
\hline European Commission & & & & & & & & & 610.6 & 610.6 \\
\hline $\begin{array}{l}\text { European Commission } \\
\text { EuropeAid Co-operation } \\
\text { Office }\end{array}$ & & & & & & & & & 19 & 19 \\
\hline European Commission & & 14 & 10.4 & 0 & & 2.4 & & & 4.3 & 31.1 \\
\hline
\end{tabular}




\begin{tabular}{|l|l|l|l|l|l|l|l|l|l|l|} 
Humanitarian Aid Office & & & & & & & & & & \\
\hline ROLEX & & & & & & & & & 1 & 1 \\
\hline UNICEF NATCOMs & & & & & & & & & 241.2 & 241.2 \\
\hline $\begin{array}{l}\text { United Nations Fund for } \\
\text { International Partnerships }\end{array}$ & & 1.7 & & & & & & & 1.5 & 3.2 \\
\hline Other & & 0.5 & 0.6 & 0.1 & 0 & 0 & 0.1 & 0 & 3.3 & 4.6 \\
\hline & & & & & & & & & & \\
\hline Private $^{5}$ & & 0.2 & 1 & & & 0.5 & & & 60.9 & 62.6 \\
\hline Total & 11.1 & 810.5 & 322.3 & 6.4 & 0.26 & 39.9 & 0.53 & 4.2 & 5122.3 & 6317.5 \\
\hline
\end{tabular}

Source: Office for the Coordination of Humanitarian Affairs, United Nations, www.releifwb.int/fts.

Notes:

1. Data do not cover donations in kind (eg provided emergency shelter and household items World Vision). Only the countries/organization with commitments of more than US 5 million are separately listed.

2. Commitments made directly to individual tsunami affected countries.

3. Commitments made to multilateral relief organizations (such as UNICEF, WHO, WHO, ILO, FAO and WFO, Red Cross) and to NGOs.

4. Allocation of unmarked funds

5. Covers only contribution to governments and multilateral relief organizations. According to some estimates total private donations amounted to more than US\$ 1.5 billion (Economists 2005d). 
Table 3. Natural Disasters in Indonesia 1907-2004*

\begin{tabular}{|c|c|c|c|c|c|c|c|}
\hline & \multirow{2}{*}{$\begin{array}{l}\text { No. of } \\
\text { Events }\end{array}$} & \multirow{2}{*}{$\begin{array}{l}\text { Killed } \\
\text { (person) }\end{array}$} & \multirow{2}{*}{$\begin{array}{l}\text { Injured } \\
\text { (person) }\end{array}$} & \multirow[t]{2}{*}{ Homeless(person) } & \multirow{2}{*}{$\begin{array}{l}\text { Affected } \\
\text { (person) }\end{array}$} & \multicolumn{2}{|l|}{ Total } \\
\hline & & & & & & $\begin{array}{l}\text { Affected } \\
\text { (person) }\end{array}$ & $\begin{array}{l}\text { Damage } \\
\text { (US\$ '000) }\end{array}$ \\
\hline Drought & 11 & 9,329 & --- & --- & $4,894,220$ & $4,894,220$ & 159,200 \\
\hline Earthquake & 78 & 21,856 & 21,327 & 284,605 & $1,418,006$ & $1,723,938$ & 801,219 \\
\hline Epidemic $^{* *}$ & 30 & 3,476 & --- & $\begin{array}{ll}-- \\
\end{array}$ & 653,468 & 653,468 & --- \\
\hline Famine & 3 & 260 & $\begin{array}{l}--- \\
\end{array}$ & --- & 162,000 & 162,000 & --- \\
\hline Flood & 93 & 4,296 & 250,761 & 201,735 & $4,616,810$ & $5,069,306$ & 532,090 \\
\hline Slides & 30 & 1,615 & 443 & 29,555 & 339,337 & 369,335 & 20,039 \\
\hline Volcano & 43 & 17,945 & 3,280 & 17,500 & 961,073 & 981,853 & 344,390 \\
\hline Wave / Surge & 7 & 243,664 & 120 & 412,438 & 2,000 & 414,558 & 675,000 \\
\hline Wild Fires & 7 & 63 & 208 & --- & $3,034,000$ & $3,034,208$ & $17,235,000$ \\
\hline Wind Storm & 10 & 1,992 & 183 & 800 & 18,715 & 19,698 & --- \\
\hline TOTAL & 312 & 304,496 & 276,322 & 946,633 & $16,099,629$ & $17,322,584$ & $19,766,938$ \\
\hline $\begin{array}{l}\text { Average per } \\
\text { event }\end{array}$ & & 976 & 886 & 3,034 & 51,601 & 55,521 & 63,356 \\
\hline
\end{tabular}

Source: the Centre for Research on the Epidemiology of Disaster (CRED) Database, Universite Catholique de Luuvin (www.emdat.net)

Notes:

--- data not available.

* Including the earthquake and tsunami in Aceh on the $26^{\text {th }}$ December 2004

** Epidemics included: Plague(Bubonic), Diarrhoeal/Enteric(Cholera), Malaria, Diarrhoeal/Enteric, Arbovirus(Dengue fever), Anthrax,

Diarrhoeal/Enteric(Acute diarrhoeal syndrome), Rabies, Diarrhoeal/Enteric(Shigella suspected), Respiratory(Acute respiratory syndrome (SARS)), Arbovirus(Dengue). 
Table 4: Natural Disasters in Indonesia 1997-2004*

\begin{tabular}{|c|c|c|c|c|c|}
\hline \multirow[t]{3}{*}{ Disaster } & \multirow{3}{*}{$\begin{array}{l}\text { No. of } \\
\text { Events }\end{array}$} & \multicolumn{2}{|c|}{ Total Affected } & \multicolumn{2}{|c|}{ Total Estimated Destroyed } \\
\hline & & Killed & Refugee & Losses & Houses \\
\hline & & (person) & (person) & (million rupiah.) & (unit) \\
\hline Epidemic & 22 & 304 & --- & -- & --- \\
\hline Vulcano Eruption & 45 & 8 & 39,484 & --- & 5 \\
\hline Tsunami & 23 & 22,170 & 1,592 & 1,085 & 588 \\
\hline Earthquake & 52 & 7,574 & 17,774 & 798,064 & 17,501 \\
\hline Cyclone & 136 & 5,047 & 3,328 & 81,380 & 7,313 \\
\hline Earthslide & 219 & 435 & 8,231 & 31,286 & 2,908 \\
\hline Flood & 299 & 285 & 390,356 & 888,476 & 39,393 \\
\hline TOTAL & 796 & 36,986 & 462,116 & $1,816,427$ & 68,137 \\
\hline average per event & & 46 & 581 & 2,282 & 86 \\
\hline
\end{tabular}

Source: Indonesian Emergency Relief Coordination Agency (http://www.bakornaspbp.go.id/)

Notes

--- data not available.

* Excluding the earthquake and tsunami in Aceh on the $26^{\text {th }}$ December 2004 
Table 5: Indonesia: Number of People Affected by the Aceh Tsunami

\begin{tabular}{|l|l|l|l|l|l|l|l|}
\hline Region & Population & Killed $^{\mathrm{a}}$ & Lost $^{\mathrm{b}}$ & Hospitalized $^{\mathrm{b}}$ & Refugee $^{\mathrm{b}}$ & $\begin{array}{l}\text { Affected } \\
\text { people }\end{array}$ & $\begin{array}{l}\text { Affected/Population } \\
\mathbf{( \% )}\end{array}$ \\
\hline Aceh Province & & & & & & & \\
\hline 01. Kota Banda Aceh & 269,091 & 78,417 & 64,552 & --- & 39,509 & 182,478 & 67.8 \\
\hline 02. Kab. Aceh Besar & 306,718 & 58 & 43,902 & --- & 97,947 & 141,907 & 46.3 \\
\hline 03. Kota Sabang & 27,447 & 18 & 108 & --- & 4,403 & 4,529 & 16.5 \\
\hline 04. Kab. Pidie & 517,452 & 4,646 & 2,091 & --- & 64,613 & 71,350 & 13.8 \\
\hline 05. Kab. Bireun & 350,964 & 1,488 & 58 & 187 & 15,546 & 17,279 & 4.9 \\
\hline 06. Kab. Aceh Utara & 395,800 & 2,217 & 233 & 284 & 20,082 & 22,816 & 5.8 \\
\hline 07. Kota Lhokseumawe & 156,478 & 394 & 11 & 75 & 20,084 & 20,564 & 13.1 \\
\hline 08. Kab. Aceh Timur & 253,151 & 224 & --- & --- & 13,710 & 13,934 & 5.5 \\
\hline 09. Kota Langsa & 141,138 & --- & --- & --- & 10,370 & 10,370 & 7.3 \\
\hline 10. Kab. Aceh Tamiang & 238,718 & --- & --- & --- & 3,100 & 3,100 & 1.3 \\
\hline 11. Kab. Aceh Jaya & 111,671 & 19,661 & 77 & --- & 40,382 & 60,120 & 53.8 \\
\hline 12. Kab. Aceh Barat & 97,523 & 11,830 & 2,911 & --- & 78,817 & 93,558 & 95.9 \\
\hline 13. Kab. Nagan Raya & 152,748 & 493 & 865 & --- & 14,769 & 16,127 & 10.6 \\
\hline 14. Kab. Aceh Barat Daya & 153,411 & 835 & --- & --- & 13,964 & 14,799 & 9.6 \\
\hline 15. Kab. Aceh Selatan & 167,052 & 6 & 1,086 & 10 & 16,188 & 17,290 & 10.4 \\
\hline 16. Kab. Simeuleu & 76,629 & 22 & 1 & 135 & 18,009 & 18,167 & 23.7 \\
\hline 17. Kab. Aceh Singkil & 174,007 & 73 & 4 & --- & 106 & 183 & 0.1 \\
\hline 18. Kab. Aceh Tengah & 158,641 & 192 & 227 & 229 & 4,005 & 4,653 & 2.9 \\
\hline 19. Kab. Aceh Tenggara & 168,034 & 26 & --- & --- & --- & 26 & --- \\
\hline 20. Kab. Gayo Lues & 67,514 & 27 & --- & --- & --- & 27 & --- \\
\hline 21. Kab. Bener Meriah & 120,000 & 36 & --- & --- & 1,204 & 1,240 & 1.0 \\
\hline & & & & & & & \\
\hline Total Aceh & $\mathbf{4 , 1 0 4 , 1 8 7}$ & $\mathbf{1 2 0 , 6 6 3}$ & $\mathbf{1 1 6 , 1 2 6}$ & $\mathbf{9 2 0}$ & $\mathbf{4 7 6 , 8 0 8}$ & $\mathbf{7 1 4 , 5 1 7}$ & $\mathbf{1 7 . 4}$ \\
\hline & & & & & & & \\
\hline $\begin{array}{l}\text { North Sumatra } \\
\text { Province }\end{array}$ & & & & & & & \\
\hline 01. Kab. Nias & 422,170 & 233 & 24 & --- & 4,000 & 4,257 & $1.0 \%$ \\
\hline & & & & & & \\
\hline
\end{tabular}




\begin{tabular}{|l|l|l|l|l|l|l|l|}
\hline 02. Kab. Nias Selatan & 275,422 & 1 & --- & --- & n.a. & 1 & $0.0 \%$ \\
\hline 03. Kab. Tapanuli Tengah & 272,333 & 1 & --- & --- & n.a. & 1 & $0.0 \%$ \\
\hline 04. Kab. Serdang Bedagai & 549,091 & 4 & --- & 2 & n.a. & 6 & $0.0 \%$ \\
\hline $\begin{array}{l}\text { 05. Kab. Mandailing } \\
\text { Natal }\end{array}$ & 369,691 & 1 & --- & --- & n.a. & 1 & $0.0 \%$ \\
\hline & & & & & & & \\
\hline Total North Sumatra & $1,888,707$ & $\mathbf{2 4 0}$ & $\mathbf{2 4}$ & $\mathbf{2}$ & $\mathbf{4 , 0 0 0}$ & $\mathbf{4 , 2 6 6}$ & $0.2 \%$ \\
\hline & & & & & & & \\
\hline In Medan & --- & --- & --- & 2,509 & 18,342 & 20,851 & --- \\
\hline In Jakarta & --- & --- & --- & --- & 1,567 & 1,567 & --- \\
\hline Total & $\mathbf{5 , 9 9 2 , 8 9 4}$ & $\mathbf{1 2 0 , 9 0 3}$ & $\mathbf{1 1 6 , 1 5 0}$ & $\mathbf{3 , 4 3 1}$ & $\mathbf{5 0 0 , 7 1 7}$ & $\mathbf{7 4 1 , 2 0 1}$ & $\mathbf{1 2 . 4 \%}$ \\
\hline
\end{tabular}

Notes:

$\mathrm{a}=$ Bakornas PBP on 31 January 2005

b = Dep. Social on 17 February 2005

$\mathrm{c}=$ These are not all the provinces in North Sumatra; only affected districts

--- data not available 
Table 6. Indonesia: Estimated Damages and Losses

\begin{tabular}{|c|c|c|c|c|c|}
\hline & \multicolumn{3}{|c|}{ Total Impact } & \multicolumn{2}{|c|}{ Property } \\
\hline & Damage & Losses & Total & Private & Public \\
\hline Social Sectors & 1674.9 & 65.8 & 1740.7 & 1440.6 & 300.1 \\
\hline Housing & 1398.3 & 38.8 & 1437.1 & 1408.4 & 28.7 \\
\hline Education & 110.8 & 17.6 & 128.4 & 9 & 119.4 \\
\hline Health & 82.5 & 9.4 & 91.9 & 23.2 & 68.6 \\
\hline Culture and Religion & 83.4 & & 83.4 & & 83.4 \\
\hline Infrastructure & 636 & 240.8 & 876.8 & 325.9 & 550.8 \\
\hline Transport & 390.5 & 145.4 & 535.9 & 165.8 & 370.1 \\
\hline Communications & 18.9 & 2.9 & 21.8 & 8.6 & 13.2 \\
\hline Energy & 67.8 & 0.1 & 67.9 & 1.1 & 66.9 \\
\hline Water and Sanitation & 26.6 & 3.2 & 29.8 & 18.3 & 11.4 \\
\hline $\begin{array}{l}\text { Flood control, irrigation and sea } \\
\text { protection works }\end{array}$ & 132.1 & 89.1 & 221.2 & 132.1 & 89.1 \\
\hline Productive Sectors & 351.9 & 830.2 & 1182.1 & 1132 & 50.1 \\
\hline Agriculture and Livestock & 83.9 & 140.9 & 224.8 & 194.7 & 29.9 \\
\hline Fisheries & 101.5 & 409.4 & 510.9 & 508.5 & 2.5 \\
\hline Enterprises & 166.6 & 280 & 446.6 & 428.9 & 17.7 \\
\hline Cross Sectoral & 257.6 & 394.4 & 652 & 562.9 & 89.1 \\
\hline Environment & 154.5 & & 154.5 & 548.9 & \\
\hline Governance and administration & 89.1 & & 89.1 & & 89.1 \\
\hline Bank and Finance & 14 & & 14 & 14 & \\
\hline Total Impact & 2920.4 & 1531.2 & 4451.6 & 3461.4 & 990.1 \\
\hline
\end{tabular}

Source: World Bank (2005) 
Table 7: Indonesia: Estimated Damages

as Percentage of Pre-disaster Levels

\begin{tabular}{|l|l|}
\hline Items & $\begin{array}{l}\text { Damages in } \\
\text { Percentage }\end{array}$ \\
\hline Road & 31.7 \\
\hline School & 30.0 \\
\hline Hospital & 33.3 \\
\hline Health Centre & 24.0 \\
\hline Permanent House & 26.9 \\
\hline Non-Permanent House & 30.4 \\
\hline Irrigated Paddy Field & 24.9 \\
\hline Non-irrigated Paddy Field & 32.4 \\
\hline Estate Crop & 27.9 \\
\hline Community Forest & 28.3 \\
\hline Non-Oil/Gas Industry & 27.4 \\
\hline Source: LPEM(2005). &
\end{tabular}

Source: LPEM (2005). 
Table 8: Sri Lanka: Impact of Tsunami (as at 25 January)

\begin{tabular}{|c|c|c|c|c|c|c|c|c|c|c|}
\hline \multirow[t]{2}{*}{ Province } & \multirow[t]{2}{*}{ District } & \multirow{2}{*}{$\begin{array}{l}\text { No of } \\
\text { affected } \\
\text { families }\end{array}$} & \multirow{2}{*}{$\begin{array}{l}\text { No of } \\
\text { displaced } \\
\text { families }\end{array}$} & \multicolumn{3}{|c|}{ Displaced persons } & \multirow{2}{*}{$\begin{array}{l}\text { Number } \\
\text { of death }\end{array}$} & \multirow{2}{*}{$\begin{array}{l}\text { Number } \\
\text { of } \\
\text { missing } \\
\text { people }\end{array}$} & \multicolumn{2}{|c|}{ Impact on property } \\
\hline & & & & $\begin{array}{l}\text { In } \\
\text { welfare } \\
\text { centers }\end{array}$ & $\begin{array}{l}\text { With } \\
\text { relatives }\end{array}$ & Total & & & $\begin{array}{l}\text { No. of } \\
\text { completely } \\
\text { damaged } \\
\text { houses }\end{array}$ & $\begin{array}{l}\text { No of } \\
\text { partly } \\
\text { damaged } \\
\text { houses }\end{array}$ \\
\hline \multirow[t]{3}{*}{ North } & Jaffna & 13652 & 12631 & 11891 & 28016 & 39907 & 2640 & 540 & 6084 & 1114 \\
\hline & Killinochchi & 2295 & 318 & 305 & 1298 & 1603 & 560 & 1 & 1250 & 4250 \\
\hline & Mulativ & --- & 6007 & 11993 & 10564 & 22557 & 3000 & 552 & 3400 & 600 \\
\hline \multirow[t]{3}{*}{ Eastern } & Trincomalee & --- & 27494 & 19559 & 62084 & 81643 & 1078 & 337 & 5974 & 10394 \\
\hline & Baticaloa & 63717 & 12494 & 30403 & 31509 & 61912 & 2840 & 1033 & 15939 & 5665 \\
\hline & Ampara & 38624 & $\begin{array}{ll}-- \\
--\end{array}$ & 75172 & --- & 75172 & 10436 & 876 & 29077 & $\begin{array}{c}-- \\
--\end{array}$ \\
\hline \multirow[t]{3}{*}{ Southern } & Hambantota & 16994 & 3334 & 555 & 17168 & 17723 & 4500 & 963 & 2303 & 1744 \\
\hline & Matara & 20675 & 3268 & 4141 & 9254 & 13395 & 1342 & 613 & 2362 & 5659 \\
\hline & Galle & 23174 & 1472 & 4830 & 123247 & 128077 & 4216 & 554 & 5525 & 5966 \\
\hline \multirow[t]{3}{*}{ Western } & Kalutara & 6905 & 6905 & 3281 & 24432 & 27713 & 256 & 155 & 2780 & 3116 \\
\hline & Colombo & 9647 & 5290 & 5999 & 25240 & 31239 & 79 & 12 & 3398 & 2210 \\
\hline & Gampaha & 6827 & 308 & 876 & 573 & 1449 & 6 & 5 & 292 & 307 \\
\hline $\begin{array}{l}\text { North } \\
\text { Western }\end{array}$ & Putlam & 232 & 18 & 66 & & 66 & 4 & 3 & 23 & 72 \\
\hline \multicolumn{2}{|l|}{ Total } & 202742 & 79791 & 169071 & 333385 & 502456 & 30957 & 5644 & 78407 & 41097 \\
\hline
\end{tabular}

Source: Sri Lanka, Department of Census and Statistics <www.statistics.gov.lk/tsunami/index.htm> 
Table 9: Sri Lanka: Preliminary Estimates of Asset Losses due to Tsunami and Financial Needs for Reconstruction

\begin{tabular}{|l|l|l|l|l|}
\hline Sector & Asset losses & Reconstruction needs & \\
\hline & & Short term & $\begin{array}{l}\text { Medium } \\
\text { term }\end{array}$ & Total \\
\hline Housing & $360-341$ & 50 & $387-437$ & $437-487$ \\
\hline Roads & 60 & 25 & 175 & 200 \\
\hline Water and sanitation & 42 & 64 & 53 & 117 \\
\hline Railway & 15 & 40 & 90 & 130 \\
\hline Education & 26 & 13 & 32 & 45 \\
\hline Health & 60 & 17 & 67 & 84 \\
\hline Agriculture & 3 & 2 & 2 & 4 \\
\hline Fisheries & 97 & 69 & 49 & 118 \\
\hline Tourism & 250 & 130 & & 130 \\
\hline Power & 10 & 27 & $40-50$ & $67-77$ \\
\hline Environment & 10 & 6 & 12 & 18 \\
\hline Social welfare & & 30 & & 30 \\
\hline $\begin{array}{l}\text { Miscellaneous and } \\
\text { contingency expenses }\end{array}$ & 90 & 30 & 120 & 150 \\
\hline Total, US\$ million & $970-1000$ & 500 & $1000-1100$ & $1500-1600$ \\
\hline Percent of GDP & $4.4-4.6$ & & & $7.0-7.3$ \\
\hline
\end{tabular}

Source: ADB, JBIC and World Bank (2005) 
Figure 1. Indonesia: Earthquakes above 5 on Richter scale, 1007 - 2005

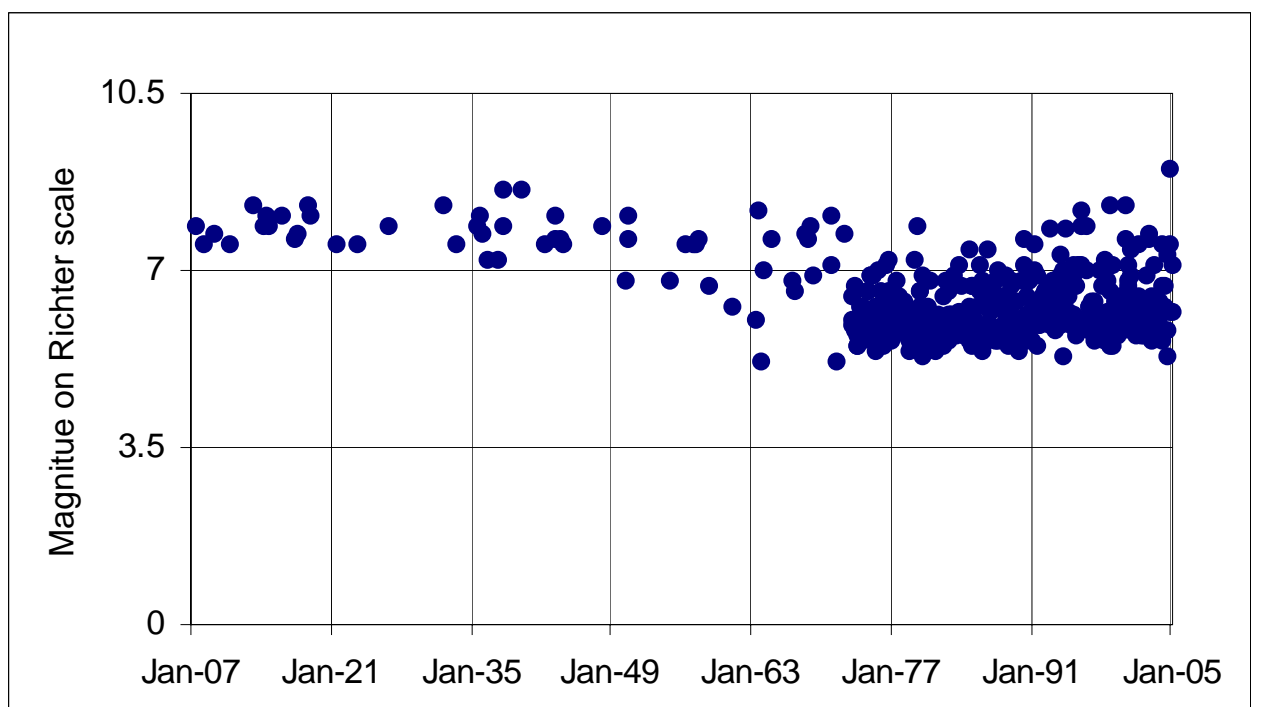

Source: USGS (2005) 
Figure 2: US dollar - Sri Lankan Rupee Daily Exchange Rate ${ }^{*}, 12$ December 2004 - 6 April 2005

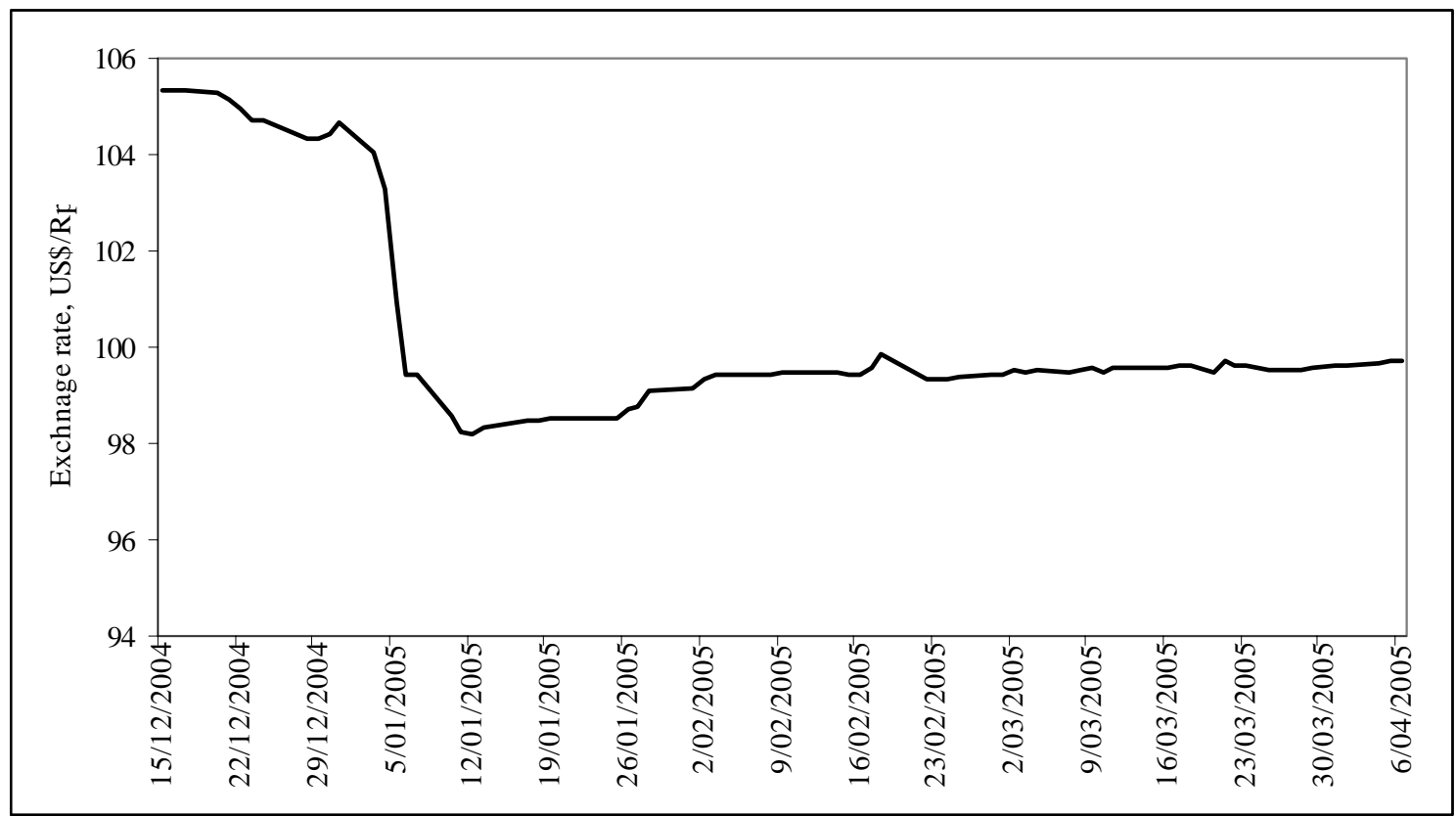

* Commercial bank middle rate (average of buying and selling rates) for transaction with customers

Source: Central Bank of Sri Lanka, http://www.lanka.net/centralbank/dailyexch.htm1 
Map 1: Indian Ocean Earthquake/Tsunami Disaster Area

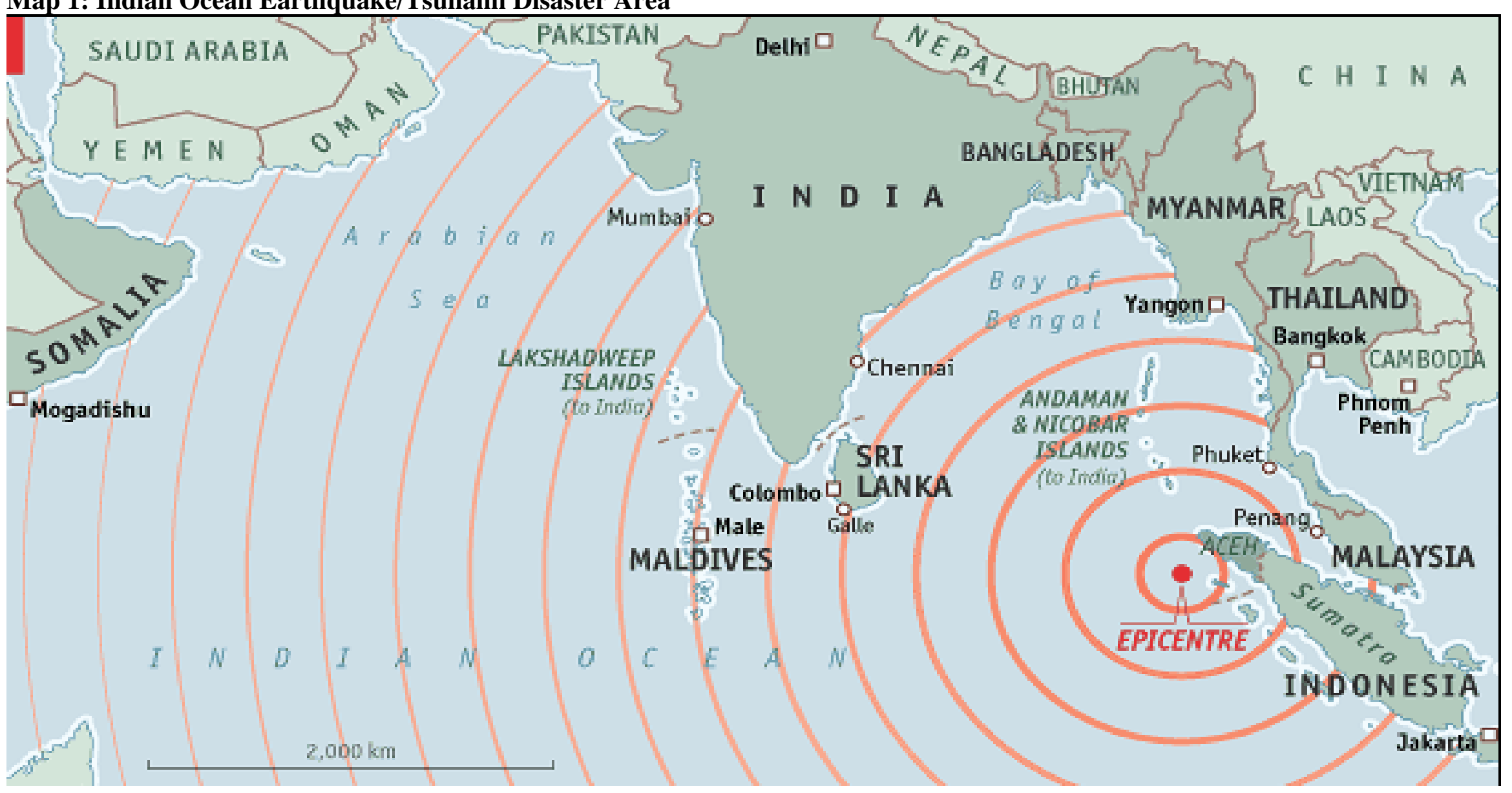

Source: Economist 2005b 


\section{Map 2: Sri Lanka: Tsunami Disaster Areas}

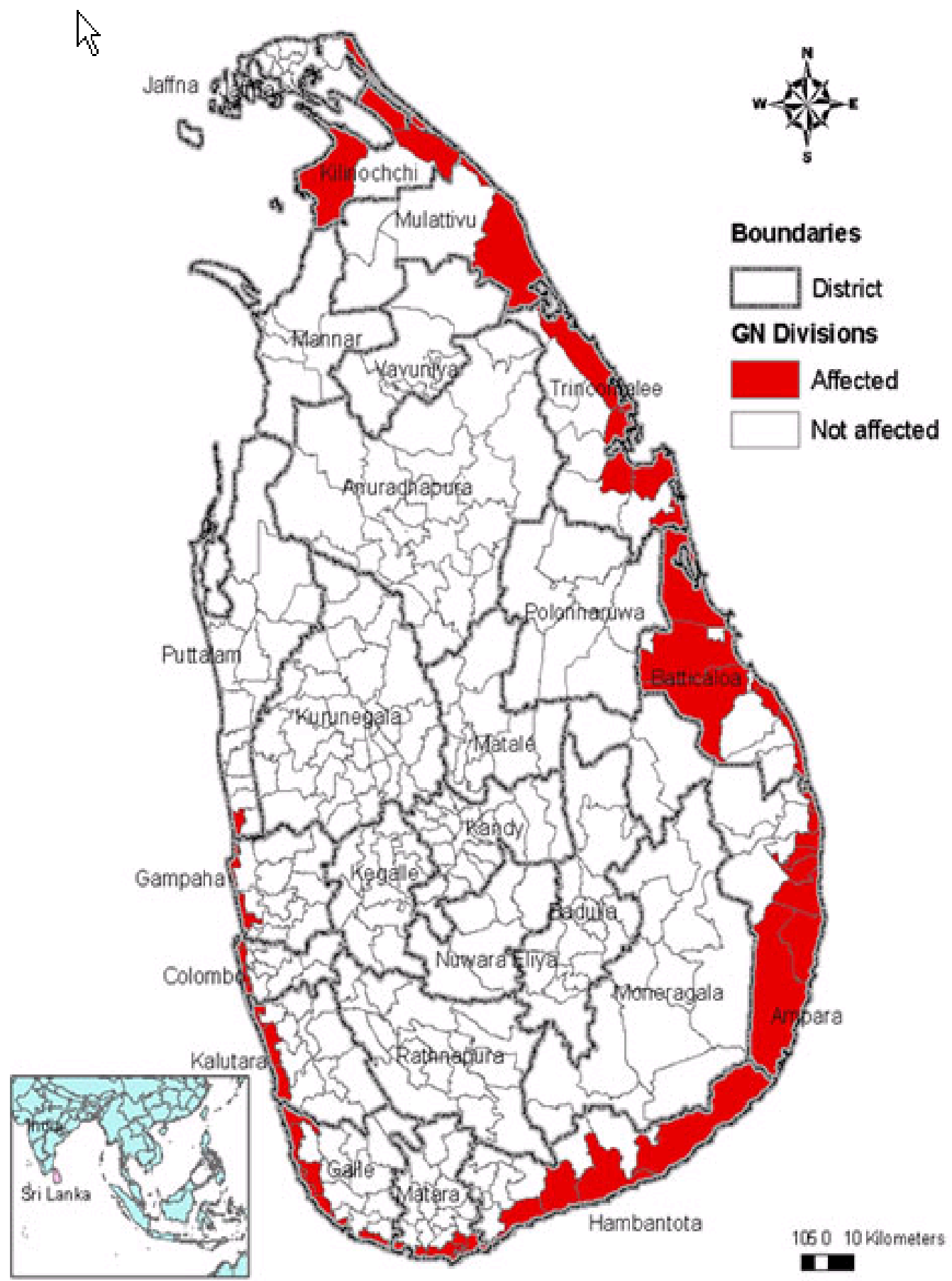

Source : Department of Census and Statistics, Colombo 
